\title{
Sex-ratios and work in Latin American households: Evidence from Mexico, Peru, Ecuador, Colombia, and Chile'
}

Juan Carlos Campaña², J. Ignacio Gimenez-Nadal ${ }^{3}$, Jose Alberto Molina ${ }^{4}$

1 This paper has benefitted from funding from the Spanish Ministry of Science and Innovation (Project "PID2019:108348RA-I00") and the Government of Aragón (Grant S32_20R)

2 Department of Economics and Business, Antonio de Nebrija University, Madrid, Spain. Contact: jcampana@nebrija.es.

3 Department of Economics Analysis, University of Zaragoza, and IEDIS, Zaragoza, Spain. Contact:ngimenez@unizar.es.

4 Department of Economics Analysis, University of Zaragoza, IEDIS and IZA, Zaragoza, Spain. Contact: jamolina@unizar.es.

\begin{abstract}
We analyze the relationship between sex-ratios in the region of residence, and the time devoted to paid and unpaid work by couples in Mexico (2002, 2009, 2014), Peru (2010), Ecuador (2012), Colombia (2012, 2017) and Chile (2015). We find that sex-ratios are negatively related to the time devoted by women to paid work in Ecuador, and positively related to the time devoted by men to paid work in Mexico and Chile. In Colombia, sex-ratios are negatively related to the time devoted by men to unpaid work, while in Mexico and Peru they are negatively related to the time devoted by women to unpaid work. These results illustrate the importance of studying this topic in countries where the evidence is scarce, mainly due to limitations in the data.
\end{abstract}

Keywords: Household, Sex-ratios, Labour supply, unpaid work, Latin America countries

JEL: D10, J22. 


\section{Introduction}

In this paper, we analyze the factors related to the time men and women living in couples devote to paid and unpaid work in Latin America, with particular attention to the sex-ratio. The sex-ratio, defined as the relative number of men to women in a marriage market, plays an important role in household decisions affected by the price of marriage (Grossbard, 2014). Since the work of Groves and Ogburn (1928) and empirical work by Cox (1940) and Easterlin (1968), academics have increasingly shown interest in the effect of sex-ratios in modern societies. ${ }^{1}$ Sex-ratios have been analyzed by demographers who have studied their effects on marriage rates (Glick, Beresford and Heer, 1963; Henry 1975; Goldman 1977; Schoen 1983; Goldman, Westoff and Hammerslough, 1984) and since Becker (1973), economists have analyzed the relationship between the sex-ratio and aspects of labor supply (Grossbard-Shechtman, 1984; Angrist, 2002; Chiappori, Fortin and Lacroix, 2002; Rapopport, Sofer and Solaz, 2011; Grossbard, 2014; Molina, Gimenez-Nadal and Velilla, 2018), household bargaining (Becker 1991; Chiappori, Fortin and Lacroix, 2002; Rapopport, Sofer and Solaz, 2011; Molina, Gimenez-Nadal and Velilla, 2018) and savings (Wei and Zhang, 2011; Du and Wei, 2013).

As shown by United Nations (2015), large variations in the ratio of men to women are found across the world, with some regions experiencing a shortage of men and others a shortage of women, with a shortage of men in Latin America and the Caribbean being among the highest in the world. Imbalances in sex-ratios may have implications for both paid and unpaid work, since women in a marriage market with relatively high sex-ratios are less likely to participate in the labor market, and more likely to engage in home activities (Grossbard-Shechtman, 2003). Grossbard (2014) shows that when sex-ratios are relatively high, women have greater personal disposable income and thus less need to obtain their own income from employment, leading to lower participation in the labor market. Angrist (2002) uses U.S. data and finds that an increase in the sex-ratios reduces the labor force participation of married women and their hours worked. Similarly, according to Chiappori, Fortin and Lacroix (2002) for the US, an increase in the sex-ratio reduces wives' labor supply, whereas it increases husbands' labor supply. However, the evidence on the relationship between the sex-ratio and labor supply is scarce for Latin American countries, despite the flourishing literature on the determinants of time allocation in that region (Newman 2002; Medeiros, Osorio and Costa, 2010; Milosavljevic 2007; Esplen, 2009; Gammage 2010; Canelas and Salazar 2014; Calero, Dellavalle and Zanino, 2016; Campaña, Gimenez-Nadal and Molina, 2018).

One of the most significant changes in Latin America has been the growing economic contribution of women, due mainly to the female labor force participation rates in countries of Latin America and the Caribbean growing from 41.5\% in 1990 to 52\% in 2020 (World Bank, 2021), which is consistent with the increase in women's education (CEPAL, 2014). But despite this increase, specialization within the household has changed very little, and women continue to do most of the unpaid labor, particularly domestic labor and caring. One commonality that has been found, independently of the characteristics of the countries and the type of time use surveys and/or modules used to collect time use data of individuals, is that women in Latin-America devote relatively more time to unpaid work than do men (Canelas and Salazar 2014). This is the case in Ecuador (Newman 2002; Canelas and Salazar, 2014; Campaña, Gimenez-Nadal and Molina, 2018), Bolivia (Medeiros, Osorio and Costa, 2010; Canelas and Salazar 2014), Guatemala (Canelas and Salazar 2014), Nicaragua (Aguilar, Espinosa and Argeñal, 2004; Esquivel, Budlender, Folbre, and Hirway, 2008), Mexico (Campaña, Gimenez-Nadal and Molina, 2018), Peru (Campaña, Gimenez-Nadal and Molina, 2018), and Argentina (Esquivel 2010), among others.

In these countries, characterized by traditional roles in which men are income providers in marriage and women are homemakers (Campaña, Gimenez-Nadal and Molina, 2018), and

1 The empirical work from $\underline{\operatorname{Cox}(1940)}$ and Easterlin (1968) focused on linking the sex ratio to marriage outcomes and fertility rates. 
where the primary responsibility for the care of the sick, the elderly, and children still falls to women (Folbre, 2006; Esplen, 2009), increases in sex-ratios may be related to increases in women's paid work and decreases in their unpaid work (Grossbard-Shechtman, 2003). ${ }^{2}$ Furthermore, the increase in sex-ratios causes a redistribution of income from men to women, and this redistribution may also influence aggregate consumption (Chiappori, Fortin and Lacroix, 2002).

Within this framework, we use data from time use surveys in Mexico (2002, 2009, 2014), Peru (2010), Ecuador (2012), Colombia $(2012,2017)$ and Chile (2015) to analyze the time devoted to paid and unpaid work by men and women living in couple, with a special focus on the relationship between the sex-ratios and the time devoted by men and women to these activities. In our econometric analysis, we take into account the relationship between both time use activities and spouses 'time allocation decisions, estimating a linear model of four seemingly unrelated regressions (two equations for each member of the couple). We find that the sex-ratio in Ecuador is negatively related to the time devoted by women to paid work, and is positively related to the time devoted by men to paid work in Mexico and Chile. In the case of unpaid work, we find that the sex-ratio in Colombia is negatively related to the time devoted by men to unpaid work., while in Mexico and Peru it is negatively related to the time devoted by women to unpaid work. In Ecuador, our results show that an increase of one percentage point in the sex-ratio reduces the time devoted by women to paid work by 0.28 hours per week. In Mexico and Chile an increase of one percentage point in the sex-ratio increases the time devoted by men to paid work by 0.19 and 1.00 hour per week, respectively. Regarding unpaid work, in Colombia an increase of one percentage point in the sex-ratio reduces the time devoted by men to unpaid work by 0.12 hours per day, and it decreases the time devoted by women to unpaid work in Mexico and Peru by 0.32 and 0.89 hours per week, respectively.

We contribute to the literature by analyzing the time devoted to paid and unpaid work by men and women in couples in these countries, highlighting the relationships between the sex-ratio and the paid and unpaid work time. This analysis of paid and unpaid work of couples in five Latin American countries gives us a picture of how socio-demographic factors and the sex ratio, are related to those activities. Cross-country differences may help to redefine and/or develop explanatory economic models. Furthermore, we contribute evidence to the literature of sex ratios for Latin American countries, as most of the existing applied empirical work has focused on analyzing the influence of sex-ratios on paid work for developed countries (Angrist, 2002; Chiappori, Fortin and Lacroix, 2002; Molina, Gimenez-Nadal and Velilla, 2018) with little empirical evidence regarding the influence of the sex-ratio on unpaid work (Rapopport, Sofer and Solaz, 2011). As Grossbard (2014) indicates, more empirical research is needed on how the sex-ratio affects economic behaviors.

The rest of the paper is organized as follows. Section 2 describes the data. Section 3 describes the empirical strategy. Section 4 presents our results and Section 5 concludes.

\section{Data}

We use the information in time use surveys for Mexico (2002, 2009, 2014), Peru (2010), Ecuador (2012), Colombia $(2012,2017)$ and Chile $(2015)^{3}$. These surveys are representative at the national level, and the targeted populations are household members aged 12 and above, for Mexico, Peru, Ecuador, and Chile, and aged 10 and above for Colombia. Time use surveys

2 See Grossbard (2003) and Grossbard and Amuedo-Dorantes (2007) for a description of the concept of marriage market and price in marriage, which is important in our context.

3 The methodologies for the time use surveys used in this paper have been defined by the relevant institutes of statistics in each country: INEGI (National Institute of statistics and geography) in Mexico, INEI (National Institute of Statistics and Informatics) in Peru, INEG (National Institute of statistics and censuses) in Ecuador, INE (National Institute of statistics) in Chile, and DANE (National Administrative Department of statistics) in Colombia. 
provide us with information on individual time use, and are typically used to analyze individual time-allocation decisions (Aguiar and Hurst, 2007; Bianchi, 2000; Folbre, Yoon, Finnoff and Fuligni, 2015; Gershuny, 2000; Gimenez-Nadal and Sevilla, 2012; Gimenez-Nadal and Molina 2015; Campaña, Gimenez-Nadal and Molina, 2018). ${ }^{4}$ The five surveys use a list of pre-coded activities to classify and order different activities, and we use the Classification of Time-Use Activities for Latin America and the Caribbean (CAUTAL)..$^{5}$ An important characteristic of these particular surveys is that they do not allow for the consideration of simultaneous or "secondary" activities (activities done at the same time as the primary or main activity), which have been found to increase the amount of household production (Kalenkoski and Foster, 2015). It is important to consider secondary activities, given that there may be worker differentials in the ability to multitask (Floro and Pichetpongsa 2010). Thus, the consideration of secondary activities could change the conclusions obtained in this research (Esquivel et al. 2008; Esquivel 2010).

Our study sample consists of heterosexual couples (married or cohabiting) where both partners have answered all sections of the survey, and are not students or retirees. Both partners have positive hours of market work. After these restrictions are fulfilled, our study sample is 6,202 couples in Mexico, 963 couples in Peru, 1,178 couples in Ecuador, 9,842 couples in Colombia, and 1,215 couples in Chile. For the definition of the time devoted to paid work and unpaid work, we follow ECLAC (2015). ${ }^{6}$ Paid work includes all the time spent working in the paid sector. Unpaid work includes any time spent in the preparation of meals, cleaning, laundry, ironing, dusting, vacuuming, maintenance (including painting and decorating), time spent on the procurement of goods and services (that is, making purchases of groceries, shopping for items for the home), along with time spent on other productive activities at home, such as outdoor cleaning and vehicle repair. The surveys for Mexico, Peru, Ecuador, and Chile take the previous week as reference period, while for Colombia the reference period is the previous day. ${ }^{7}$

Table 1 shows summary statistics for the time devoted to paid and unpaid work for our analyzed samples. Regarding the time devoted to paid work, in the five countries, men devote more time to paid work and less time to unpaid work than do women. In Mexico, men dedicate 57.32 hours per week to paid work while women dedicate 41.89. Men devote 11.16 hours per week to unpaid work while women devote 36.16 hours per week. In Peru, men dedicate 57.15 hours per week to paid work while women dedicate 36.45 , and men devote 10.96 hours per week to unpaid work while women devote 33.73. In Ecuador, men dedicate 52.03 hours per week to paid work while women dedicate 42.87 , and men devote 8.15 hours per week to unpaid work and women devote 33.93. In Colombia, men dedicate 9.53 hours per day to paid work while women dedicate 8.07. Men devote 0.78 hours per day to unpaid work while women devote 3.04. In Chile, men dedicate 56.25 hours per week to paid work while women dedicate 46.83, and men devote 13.13 hours per week to unpaid work while women devote 29.06 .

4 The advantage of the time-use surveys that we are using here, over stylized-questions such as those included in labor force surveys, where respondents are asked how much time they have spent in the previous week, or normally spend each week, on market work or housework, is that there is a clear separation between housework and childcare time, which may reduce measurement error when individuals tend to include childcare time as part of housework, which may crucially bias the results. It is important to distinguish between unpaid work and child care, since, as pointed out by Sevilla-Sanz et al. (2010) and Gimenez-Nadal and Molina (2013), those women who have a better position in the labour market, reduce their time devoted to unpaid work but also increase their time devoted to child care.

5 For more information regarding Classification of Time-Use Activities for Latin America and the Caribbean see ECLAC $\underline{(2015) \text {. }}$

6 See Appendix A for a description of all the activities included in the two categories.

7 In unpaid work, we do not include child care. Kahneman and Krueger (2006) and Krueger (2007) show that the time parents spend on children is an enjoyable activity that offers a different level of (experienced) utility compared to unpaid work, indicating that unpaid work and child care have a different significance. Therefore, it is necessary that these activities are treated separately. Our objective in this research is to analyze paid work and unpaid work and that is why we exclude child care, leaving this activity for future research. In the case of Colombia, as the information refers to the previous day, which could be a weekday or a weekend day, it would not be methodologically correct to multiply by 7 . For this reason, and following Campaña, Gimenez-Nadal and Molina $(2017,2020)$, the comparison of Colombia with other countries continues to be in hours per day and not hours per week. 
Table 1. Descriptive statistics of the data (couples)

\begin{tabular}{|c|c|c|c|c|c|c|c|c|c|c|}
\hline \multirow[b]{2}{*}{ Variable } & \multicolumn{2}{|c|}{ Mexico } & \multicolumn{2}{|c|}{ Peru } & \multicolumn{2}{|c|}{ Ecuador } & \multicolumn{2}{|c|}{ Colombia } & \multicolumn{2}{|c|}{ Chile } \\
\hline & Mean & $\begin{array}{l}\text { Standard } \\
\text { Deviation }\end{array}$ & Mean & $\begin{array}{c}\text { Standard } \\
\text { Devia- } \\
\text { tion }\end{array}$ & Mean & $\begin{array}{l}\text { Standard } \\
\text { Deviation }\end{array}$ & Mean & $\begin{array}{l}\text { Standard } \\
\text { Deviation }\end{array}$ & Mean & $\begin{array}{l}\text { Standard } \\
\text { Deviation }\end{array}$ \\
\hline \multicolumn{11}{|c|}{ Hours devoted to paid work* } \\
\hline Men & 57.32 & 17.72 & 57.15 & 14.73 & 52.03 & 14.69 & 9.53 & 2.40 & 56.25 & 17.41 \\
\hline Women & 41.89 & 19.80 & 36.45 & 18.95 & 42.87 & 15.51 & 8.07 & 2.71 & 46.83 & 17.65 \\
\hline \multicolumn{11}{|c|}{ Hours devoted to unpaid work** } \\
\hline Men & 11.16 & 10.49 & 10.96 & 7.53 & 8.15 & 9.2 & 0.78 & 1.21 & 13.13 & 12.90 \\
\hline Women & 36.16 & 17.39 & 33.73 & 12.68 & 33.93 & 16.58 & 3.04 & 2.18 & 29.06 & 17.55 \\
\hline \multicolumn{11}{|l|}{ Income $e^{* * *}$} \\
\hline $\begin{array}{l}\text { Men hourly } \\
\text { wage (in \$US) }\end{array}$ & 2.39 & 4.47 & 1.73 & 1.49 & 2.13 & 1.85 & 2.29 & 2.31 & 4.46 & 3.61 \\
\hline $\begin{array}{l}\text { Women hourly } \\
\text { wage (in \$US) }\end{array}$ & 2.15 & 3.44 & 1.70 & 2.07 & 1.87 & 1.78 & 2.00 & 2.03 & 3.37 & 2.82 \\
\hline $\begin{array}{l}\text { Monthly non-la- } \\
\text { bor household } \\
\text { income (in \$US) }\end{array}$ & 25.04 & 168.11 & - & - & 46.98 & 366.37 & 49.58 & 216.94 & 36.12 & 126.83 \\
\hline \multicolumn{11}{|c|}{ Demographic indicator } \\
\hline Sex-ratio & 95.09 & 3.64 & 98.62 & 4.49 & 97.20 & 5.53 & 96.03 & 6.75 & 95.19 & 1.72 \\
\hline \multicolumn{11}{|c|}{ Household characteristics } \\
\hline N. children $0-4$ & 0.28 & 0.53 & 0.33 & 0.53 & 0.28 & 0.55 & 0.24 & 0.48 & 0.24 & 0.48 \\
\hline N. children 5-12 & 0.70 & 0.88 & 0.81 & 0.89 & 0.75 & 0.90 & 0.57 & 0.75 & 0.43 & 0.66 \\
\hline $\begin{array}{l}\text { N. children } \\
13-17\end{array}$ & 0.44 & 0.67 & 0.54 & 0.70 & 0.45 & 0.68 & 0.36 & 0.61 & 0.27 & 0.49 \\
\hline $\begin{array}{l}\text { N. other house- } \\
\text { hold members }\end{array}$ & 0.63 & 1.01 & 0.63 & 1.05 & 0.66 & 0.95 & 0.56 & 0.90 & 0.78 & 1.24 \\
\hline \multicolumn{11}{|c|}{ Years of education } \\
\hline Men & 11.34 & 4.99 & 9.70 & 4.59 & 9.16 & 4.67 & 10.46 & 4.57 & 12.62 & 3.92 \\
\hline Women & 11.29 & 4.97 & 8.36 & 5.43 & 9.42 & 4.95 & 11.19 & 4.40 & 12.77 & 3.60 \\
\hline \multicolumn{11}{|c|}{ Age } \\
\hline Men & 42.37 & 11.02 & 42.68 & 9.65 & 44.30 & 12.22 & 42.33 & 11.08 & 45.19 & 11.23 \\
\hline Women & 39.43 & 10.16 & 39.48 & 9.40 & 40.88 & 11.34 & 38.87 & 10.49 & 42.76 & 10.97 \\
\hline \multicolumn{11}{|c|}{ Ethnic characeristics } \\
\hline Men indigenous & - & - & 0.19 & 0.39 & 0.07 & 0.26 & 0.05 & 0.21 & 0.06 & 0.25 \\
\hline $\begin{array}{l}\text { Women indig- } \\
\text { enous }\end{array}$ & - & - & 0.21 & 0.40 & 0.07 & 0.26 & 0.05 & 0.21 & 0.07 & 0.27 \\
\hline \multicolumn{11}{|c|}{ Regional dummies } \\
\hline Urban area**** & 0.88 & 0.33 & 0.80 & 0.40 & 0.72 & 0.45 & 0.85 & 0.35 & - & - \\
\hline Region 1 & 0.36 & 0.48 & 0.26 & 0.44 & 0.40 & 0.49 & 0.18 & 0.39 & 0.06 & 0.24 \\
\hline Region 2 & 0.23 & 0.42 & 0.34 & 0.47 & 0.56 & 0.49 & 0.23 & 0.42 & 0.03 & 0.18 \\
\hline Region 3 & 0.21 & 0.41 & 0.11 & 0.32 & 0.04 & 0.19 & 0.18 & 0.38 & 0.68 & 0.46 \\
\hline Region 4 & 0.20 & 0.40 & 0.29 & 0.45 & - & - & 0.17 & 0.38 & 0.13 & 0.34 \\
\hline Region 5 & - & - & - & - & - & - & 0.24 & 0.42 & 0.08 & 0.26 \\
\hline Region 6 & - & - & - & - & - & - & 0.002 & 0.04 & 0.02 & 0.13 \\
\hline Observations & & 6202 & & 963 & & 1178 & & 9842 & & 1215 \\
\hline
\end{tabular}

Notes: Data sources are time-use surveys from Mexico (2002,2009,2014), Peru (2010), Ecuador (2012), Colombia $(2012,2017)$ and Chile (2015). The sample is restricted to heterosexual couples who are not students or retired. *, ** Weekly hours for paid and unpaid work are considered for Mexico, Peru, Ecuador, and Chile and daily hours for paid and unpaid work are considered for Colombia. *** For Mexico 1 US dollar, equivalent to 10.17 Mexican pesos (exchange rate 2002), For Peru 1 US dollar, equivalent to 2.811 Peruvian soles. For Colombia 1 US dollar, equivalent to 1817.52 Colombian pesos (exchange rate 2012). And for Chile it is 1 US dollar, equivalent to 697.33 Chilean pesos. ****Urban area For Mexico, region 1 represents 
Table 1. (continued). Descriptive statistics of the data (couples)

the Centre region, region 2 represents the West-centre region, region 3 represents the North region and region 4 represents the South-southeast region. For Peru, region 1 represents the Rest of the Coast region, region 2 represents the Sierra region, region 3 represents the Selva region and region 4 represents Lima region. For Ecuador, region 1 represents the Sierra region, region 2 represents the Costa region and region 3 represents the Amazon region. For Colombia, region 1 represents the Atlantic region, region 2 represents the Central region, region 3 represents the Eastern region, region 4 represents the Pacific Region, region 5 represents Bogota region and region 6 represents San Andres region. For Chile, region 1 represents Norte Grande region, region 2 represents Norte Chico region, region 3 represents Central Nucleus region, region 4 represents Concepción and La Frontera regions, region 5 represents Region of the Lakes, and region 6 represents Region of the Channels.

The sex-ratio is defined as the number of men per 100 women and obtained directly from the countries' statistical offices (Grossbard-Shechtman, 2003). For Mexico, the information is obtained from the census of population and housing of Mexico (2000,2005 and 2010), for Peru from the census of population and housing of Peru (2007), for Ecuador from the census of population and housing of Ecuador (2012), for Colombia from the census of population and housing of Colombia $(2012,2017)$, and for Chile from the census population of Chile (2015). ${ }^{8}$ Our sex-ratios are computed by considering urban and rural areas for 32 federal entities of Mexico, 4 aggregated regions of Peru, 24 provinces of Ecuador, 6 aggregated regions of Colombia, and 15 provinces of Chile, which allows us to exploit regional differences at the country level. ${ }^{9}$ Averaging the sex-ratios at the country level, in Mexico, Peru, Ecuador, Colombia and Chile, there are 95.09, 98.62, 97.20, 96.03 and 95.19 men for every 100 women, respectively. ${ }^{10}$ Wages are measured as hourly wages, and non-labor household income in the five countries includes income from transfers (income from other households, and subsidies from the government or from private institutions), other income (income from renting houses, apartments, vehicles, machinery and equipment), and also includes income from bank interest and income from stocks or dividends. Hourly wages and non-labor household income are expressed in US Dollars. ${ }^{11}$

For our samples, in Mexico men's hourly wage is $\$ 2.39$, while women earn $\$ 2.15$. In Peru, men earn $\$ 1.73$, while women earn $\$ 1.70$. In Ecuador, men earn $\$ 2.13$, while women earn $\$ 1.87$. In Colombia, the hourly rates for men and women, respectively, are $\$ 2.29$ and $\$ 2.00$. In Chile, men and women, respectively, earn $\$ 4.46$ and $\$ 3.37$ per hour. Non-labor income in Mexico is $\$ 25.04$ per month, in Ecuador it is $\$ 46.98$ per month, in Colombia it is $\$ 49.58$ per month, and in Chile it is $\$ 36.12$ per month. ${ }^{12}$ Other variables considered as affecting time allocation decisions include age, education, ethnicity (indigenous), the number of children by age group, number of other household members, urban residence, and the various regions of each

8 This information is provided by INEGI (National Institute of statistics and geography) in Mexico, INEI (National Institute of Statistics and

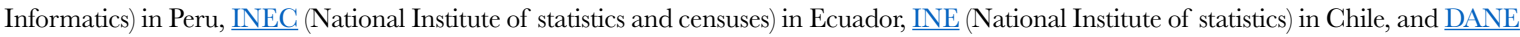
(National Administrative Department of statistics) in Colombia.

9 In the cases of Mexico, Ecuador and Chile, their Time Use Surveys show information both for federal entities/ provinces and aggregated regions, while in the cases of Peru and Colombia the information available is only for aggregated regions. It is important to indicate that in the case of Mexico, for its Time Use Surveys, urban refers to more than 2,500 inhabitants and rural refers to less than 2,500 inhabitants. In the case of Colombia, urban refers to a municipality and rural refers to not being a municipality. In the case of Chile, we are only able to compute the urban sex ratio, since its Time Use Survey only considers urban areas.

10 Grossbard and Amuedo-Dorantes (2007) and Molina, Gimenez-Nadal and Velilla (2018) show that the standard definition of sex ratio is computed by different age groups, where men and women are assigned to the same age group with an age difference of two years (as, on average, women are two years younger than men). Unfortunately, the information for the five analyzed countries was not homogeneous in terms of age. For example, in Ecuador, the information on the sex-ratio was aggregated in 5-year age ranges (the same for men as for women) so we cannot consider the difference of two years between men and women verified by the literature. Furthermore, in Mexico and Colombia, the age of individuals was general for the entire population without differentiation, in Mexico, if there are more or less than 2,500 inhabitants or, in Colombia, if they are living in a municipality or not. In Chile, we did not have the age of individuals considering whether they lived in a rural or urban area. This is a limitation of our study.

11 As in the case of Mexico, we analyze their three time use surveys (2002, 2009, 2014). We consider 2002 as the base year to deflate both the Hourly wages and non-labor household income, considering the Mexican Consumer Price Index. https://www.inegi.org.mx/app/indicesdeprecios/CalculadoraInflacion.aspx We do the same in the case of Colombia in which we analyzed its two time use surveys (2012, 2017) with 2012 as the base year https://www.dane.gov.co/index.php/estadisticas-por-tema/precios-y-costos/indice-de-precios-al-consumidor-ipc. The exchange rate used according to the years of their time use surveys, for Mexico is 1 US dollar, equivalent to 10.17 Mexican pesos (exchange rate 2002), For Peru, 1 US dollar, equivalent to 2.811 Peruvian soles. For Colombia, 1 US dollar, equivalent to 1817.52 Colombian pesos (exchange rate 2012). For Chile, 1 US dollar, equivalent to 697.33 Chilean pesos.

12 In the case of the Peruvian Time Use Survey, information on non-labor income is not available. 
country (see Table 1 for summary statistics of the variables in the five analyzed samples). ${ }^{13}$ Following Gimenez Nadal and Molina (2013) and Campaña, Gimenez Nadal and Molina (2017, 2020), we consider 3 groupings in the number of children: 0 to 4 years, 5 to 12 years, and 13 to 17 years. Ethnicity, living in a rural or urban area, ${ }^{14}$ or region of residence may also influence the time devoted to paid and unpaid work. To measure ethnic differences, we consider whether the members of the couple are indigenous, or not. ${ }^{15}$ For the region of residence of respondents, in Mexico we consider four aggregated regions (Center, West-Center, North, SouthSouth-East), in Peru we consider four aggregated regions (Rest of the Coast, Sierra, Selva, and Lima), in Ecuador we consider three aggregated regions (Sierra, Costa, and Amazon), in Colombia we consider six aggregated regions (Atlantic, Central, Eastern, Pacific, Bogota, and San Andres region), and in Chile we consider six aggregated regions (Norte Grande, Norte Chico, Central Nucleus, Concepción and La Frontera, Region of the Lakes, Region of the Channels). ${ }^{16}$

In terms of the average age in the five samples, men are three years older than women, while for years of education in the five countries, men and women have, on average, approximately the same levels (11.3 years in Mexico, 9 years in Peru, 9.3 years in Ecuador, 10.8 years in Colombia, and 12.7 years in Chile). Ethnic characteristics are similar for men and women in Peru, Ecuador, Colombia, and Chile (20\% indigenous in Peru, $7 \%$ indigenous in Ecuador, $5 \%$ indigenous in Colombia, and 6.5\% indigenous in Chile). Regarding the age ranges of the children, the greatest presence of children is found in the age group between 5 and 12 years old $(0.70,0.81,0.75,0.57$ and 0.43 number of children in Mexico, Peru, Ecuador, Colombia, and Chile, respectively).

\section{Empirical strategy}

For the time devoted by couples to paid and unpaid work in Mexico, Peru, Ecuador, Colombia, and Chile we estimate linear regressions. Frazis and Stewart (2012) argue that linear (Ordinary Least Squares, OLS) models are preferred in the analysis of time allocation decisions, while Foster and Kalenkoski (2013) compare the use of linear and Tobit models in the analysis of the time devoted to child care activities, finding that the qualitative conclusions are similar for both estimation methods. Thus, we rely on linear (OLS) models. ${ }^{17}$ Furthermore, failing to account for joint household decisions and joint provision of paid and unpaid work would affect the interpretation of the results, For instance, we consider that the time one partner devotes to housework may serve as a substitute for the time the other partner devotes to the same activities. We also consider that the time individuals spend in any activity (e.g., paid work) cannot be devoted to the other activity (unpaid work), and we cannot use individual time in any specific activity as an explanatory variable of other uses of time, since that would lead to endogeneity problems. For these reasons, we estimate a Seemingly Unrelated Regression (SUR) on the time devoted to paid work and unpaid work by both members of the couple (4 equations). ${ }^{18}$

13 The education level of individuals in Chile is under 12 years, which means that our sample selection is not fully representative of the whole population of the countries.

14 In the Time Use Survey of Chile (2015), only urban areas are considered so we cannot include this variable in the econometric estimates of this country.

15 The Mexican Time Use Survey (2002) does not have information regarding the indigenous variable, so in this case we cannot include this variable in our estimates.

16 The four aggregated regions of Mexico consider 32 federal entities, the three aggregated regions of Ecuador consider 24 provinces, and the six aggregated regions of Chile consider 15 provinces. Our sex-ratios were computed considering these federal entities/provinces for these three countries, and in the cases of Peru and Colombia we consider their aggregate regions.

17 Our results are robust to the use of Tobit models, and are available upon request.

18 Examples of studies estimating SUR models on uses of time are Connelly and Kimmel (2009), Kimmel and Connelly (2007), Gimenez-Nadal and Molina (2013) and Campaña, Gimenez-Nadal and Molina (2017). 
For a given household "i" in country "k" (k=1,2,3,4,5), let $\boldsymbol{P}_{\boldsymbol{w}} \boldsymbol{m}_{\boldsymbol{i k}}$ and $\boldsymbol{U} \boldsymbol{w \boldsymbol { m }} \boldsymbol{i k}_{\boldsymbol{k}}$ represent the time devoted to paid work and unpaid work by a man, and $\boldsymbol{P}_{\boldsymbol{w}} \boldsymbol{w} \boldsymbol{w}_{\boldsymbol{i k}}$ and $\boldsymbol{U} \boldsymbol{w} \boldsymbol{z} \boldsymbol{w}_{\boldsymbol{i k}}$ represent the time devoted to paid work and unpaid work by a woman. $\mathrm{X}_{\mathrm{ik}}$ is a vector of individual and

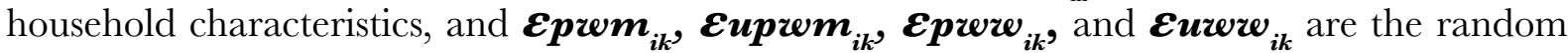
variables representing unmeasured factors. Based on this, we estimate the following equations:

$$
\begin{aligned}
& W_{j i k}=\alpha_{p w j}+\beta_{p w j} x_{i k}+\varepsilon_{p w j i k} \\
& U W_{j i k}=\alpha_{u w j}+\beta_{u w j} x_{i k}+\varepsilon_{u w j i k}
\end{aligned}
$$

where $\mathrm{j}=\mathrm{m}, \mathrm{w}(\mathrm{m}=\mathrm{man}$ and $\mathrm{w}=$ woman $) . \mathrm{X}_{\mathrm{ik}}$ includes individual and household characteristics, such as wages of both members of the couple, non-labor household income of the household, the sex-ratios (our main variable of analysis), number of children by age group, number of other household members, years of education for men and women, age and its square, ethnicity (indigenous), rural residence, and the various regions of each country). We account for correlations at the household level in the unobserved determinants of activities, by allowing the error terms to be jointly normally distributed, with no restrictions on the correlation. We further assume that the error components are independent across households. ${ }^{19}$

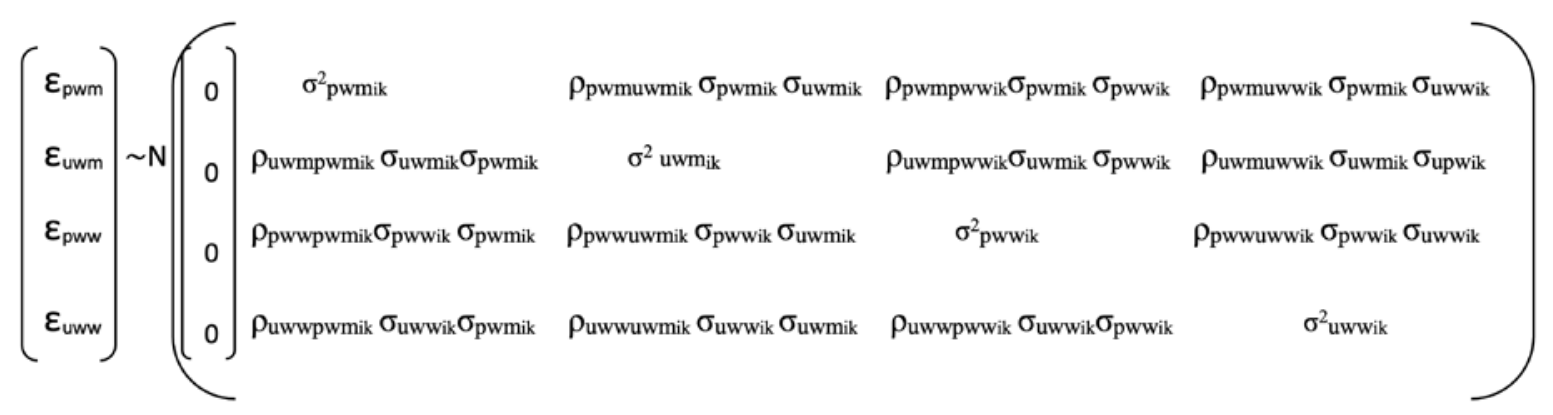

Regarding the selection of the socio-demographic characteristics used to explain paid and unpaid work, we follow prior research analyzing both paid and unpaid work time (Aguiar and Hurst, 2007, Gimenez-Nadal and Sevilla, 2012, Gimenez-Nadal and Molina, 2013; Campaña, Giménez-Nadal and Molina, 2018). With respect to wages, research has shown that higher wages lead to a better position, increasing the bargaining power within the couple (Chiappori, 1988, 1992; Lundberg and Pollak, 1993). Also, Becker's (1965) theory of the allocation of time predicts more time in paid work and less time in unpaid work as wages increase. Following Molina, Gimenez-Nadal and Velilla (2018), we define the salary of the members of the couple as the logarithm of the hourly wage of both men and women. Following these authors, we also include the cross-log wages. Non-labor household income may also affect the time devoted by individuals to their various activities (Kalenkoski, Ribar and Stratton, 2005). We include education in our estimations, given that it may affect how individuals devote their time to different activities (Guryan, Hurst and Kearney, 2008; Gimenez Nadal and Molina, 2013; Campaña, Gimenez Nadal and Molina, 2017), with higher education being related to more time in paid and less time in unpaid work.

19 Conditioning the sample on working spouses can induce a selectivity bias, especially in the case of women. However, there is some evidence that selectivity bias is probably not a problem $(\underline{\mathrm{Mroz}, 1987})$. Regarding our general analysis, we consider that correction for selection bias is not a good choice in this context, given that context heterogeneity may hinder the finding of robust and heterogeneous predictors of labor force participation. However, we also analyze the relationship of sex ratios to the extensive margin of paid work, that is, how this indicator is related to labor force participation between women and men in our analyzed countries. In table B1 of the Appendix, we consider all the couples (married/cohabiting) from our five countries. The dependent variable $=1$ if the man/woman of the couple is currently working or looking for a job, and it is 0 otherwise. We found that sex-ratios positively influence the participation of men in the labor market in Mexico, and in the case of women, positively influence their participation in the case of Mexico and negatively in the cases of Ecuador and Colombia. As can be seen, the sex-ratios influence the extensive margin for three of our five countries analyzed. 
With respect to age, Kalenkoski, Ribar and Stratton, (2005) and Aguiar and Hurst (2007) show that age and age squared must be considered in order to account for the allocation of time over the life-cycle (Apps and Rees, 2005). We also control for the number of household members and the number of children. Prior research has shown that a greater number of household members is negatively related to the time devoted by mothers to unpaid work in Mexico, Ecuador, and Colombia, and having more children is related to more time devoted by mothers to unpaid work and less time devoted to paid work in Mexico, Peru, Ecuador, and Colombia (Campaña, Gimenez Nadal and Molina, 2020).

\section{Results}

Tables 2 and 3 show the results of estimating the SUR model according to Equations (1) and (2). Columns (1), (2), (5), (6), (9) and (10) show the results of estimating Equation (1) and columns (3), (4), (7), (8), (11) and (12) show the results of estimating Equation (2), for men and women in Mexico, Peru, Ecuador, Colombia, and Chile, respectively. Concerning the variable of greatest interest, the sex-ratios, we find for Ecuador that the sex-ratio negatively influences the time devoted by women to paid work, and positively influences the time devoted by men to paid work in Mexico and Chile. The sex-ratio also has the expected sign (negative on female work, positive on male work). In the case of unpaid work, in Colombia the sex-ratio influences negatively the time devoted by men to unpaid work, while in Mexico and Peru the influence is negative for the time devoted by women to unpaid work. According to our results, a one-percentage-point increase in the sex-ratio reduces the time devoted by women to paid work in Ecuador by 0.28 hours per week, and it increases the time devoted by men to paid work in Mexico and Chile by 0.19 and 1.00 hours per week, respectively. These results are similar to those found in developed countries (Angrist, 2002; Chiappori, Fortin and Lacroix, 2002). With respect to unpaid work, a one-percentage-point increase in the sex-ratio reduces the time devoted by men to unpaid work in Colombia by 0.12 hours per day, and it decreases the time devoted by women to unpaid work in Mexico and Peru by 0.32 and 0.89 hours per week, respectively. ${ }^{20}$

Regarding hourly wages, for the time devoted to paid work in Mexico (columns 1 and 2 in Table 2), Peru (columns 5 and 6 in Table 2), Ecuador (columns 9 and 10 in Table 2) and Colombia (columns 1 and 2 in Table 3), we observe that the log of men's hourly wage is negatively related to the time devoted by men to paid work, with these results being statistically significant at standard levels, but there is no statistically significant association with the time devoted by women to paid work. The same applies to women in Mexico, Peru, and Ecuador, as the log of women's hourly wage is negatively related to the time devoted by women to paid work, with these results being statistically significant at standard levels. There is no statistically significant association with the time devoted by men to paid work in Peru and Ecuador.

20 An important issue to be considered in Latin American countries, when analyzing the time devoted to paid work, is that there are men and women who, despite that they work, do not receive a salary, as shown in ECLAC (2015). For this reason, in tables C1 and C2 (Appendix), we include all couples from our countries who are working even though they do not receive a salary. Furthermore, in paid work, we include in addition to the time dedicated to employment and commuting to and from work, the time that individuals dedicate to unpaid trainee work, employment-seeking, or setting up a business, and other work activities. Our econometric results remain similar to those obtained in Tables 2 and 3. 
Table 2. SUR estimates on the time devoted to paid work and unpaid work (couples)

\begin{tabular}{|c|c|c|c|c|c|c|c|c|c|c|c|c|}
\hline & (1) & (2) & (3) & (4) & (5) & (6) & (7) & (8) & (9) & (10) & (11) & (12) \\
\hline & \multicolumn{4}{|c|}{ Mexico } & \multicolumn{4}{|c|}{ Peru } & \multicolumn{4}{|c|}{ Ecuador } \\
\hline & Men & Women & Men & Women & Men & Women & Men & Women & Men & Women & Men & Women \\
\hline & \multicolumn{2}{|c|}{ Paid work } & \multicolumn{2}{|c|}{ Unpaid work } & \multicolumn{2}{|c|}{ Paid work } & \multicolumn{2}{|c|}{ Unpaid work } & \multicolumn{2}{|c|}{ Paid work } & \multicolumn{2}{|c|}{ Unpaid work } \\
\hline $\begin{array}{l}\text { Sex-ra- } \\
\text { tios }\end{array}$ & $0.190^{*}$ & 0.0602 & 0.0846 & $-0.321 * * *$ & 0.105 & 0.292 & -0.242 & $-0.889 * * *$ & 0.0396 & $-0.282 * *$ & -0.0621 & -0.102 \\
\hline & $(0.103)$ & $(0.114)$ & $(0.0756)$ & $(0.108)$ & $(0.342)$ & $(0.394)$ & $(0.208)$ & $(0.291)$ & $(0.131)$ & $(0.124)$ & $(0.0785)$ & $(0.134)$ \\
\hline $\begin{array}{l}\text { Log- } \\
\text { wage } \\
\text { rate } \\
\text { (men) }\end{array}$ & $-8.604^{* * * *}$ & 0.172 & 0.207 & -0.551 & $-4.512^{* * * *}$ & 0.979 & 0.498 & -1.080 & $-6.011^{* * *}$ & -0.603 & -0.531 & 0.0811 \\
\hline & $(0.582)$ & $(0.583)$ & $(0.257)$ & $(0.399)$ & $(0.942)$ & $(0.979)$ & $(0.410)$ & $(0.702)$ & $(0.991)$ & $(0.986)$ & $(0.541)$ & $(0.925)$ \\
\hline $\begin{array}{l}\text { Log- } \\
\text { wage } \\
\text { rate } \\
\text { (women) }\end{array}$ & $1.425^{* * *}$ & $-7.722 * * *$ & 0.164 & $-0.906 * *$ & -0.147 & $-6.669 * * *$ & 0.179 & $2.282 * * *$ & -0.107 & $-3.237 * * *$ & 0.813 & $-1.543^{*}$ \\
\hline & $(0.452)$ & $(0.617)$ & $(0.227)$ & $(0.375)$ & $(0.563)$ & $(0.833)$ & $(0.310)$ & $(0.512)$ & $(0.771)$ & $(0.892)$ & $(0.509)$ & $(0.838)$ \\
\hline $\begin{array}{l}\text { Cross } \\
\text { log-wag- } \\
\text { es }\end{array}$ & -0.720 & -0.242 & 0.119 & $-0.530 * *$ & $-1.287 *$ & $1.599 *$ & 0.548 & $-1.360 * *$ & 0.389 & $0.882 * *$ & 0.208 & $-0.767 *$ \\
\hline & $(0.438)$ & $(0.658)$ & $(0.115)$ & $(0.207)$ & $(0.710)$ & $(0.840)$ & $(0.367)$ & $(0.559)$ & $(0.718)$ & $(0.363)$ & $(0.386)$ & $(0.443)$ \\
\hline $\begin{array}{l}\text { Non-la- } \\
\text { bor } \\
\text { income }\end{array}$ & 0.000670 & $-9.64 \mathrm{e}-05$ & -0.000323 & 0.000672 & - & - & - & - & $3.75 \mathrm{e}-05$ & -0.000267 & $0.00274^{* * *}$ & 0.00124 \\
\hline & $(0.00149)$ & $(0.00168)$ & $(0.00136)$ & $(0.00257)$ & - & - & - & - & $(0.000692)$ & $(0.000934)$ & $(0.000347)$ & $(0.000945)$ \\
\hline $\begin{array}{l}\text { N. } \\
\text { children } \\
0-4\end{array}$ & 0.814 & $-3.361 * * *$ & -0.324 & $2.331 * * *$ & -0.821 & $-6.504^{* * * *}$ & -0.264 & $2.587 * * *$ & 0.545 & -1.507 & $-1.119^{*}$ & $2.152 *$ \\
\hline & $(0.513)$ & $(0.601)$ & $(0.417)$ & $(0.562)$ & $(0.973)$ & $(1.316)$ & $(0.532)$ & $(0.826)$ & (1.343) & $(1.486)$ & $(0.655)$ & (1.194) \\
\hline $\begin{array}{l}\text { N. } \\
\text { children } \\
5-12\end{array}$ & $0.637^{*}$ & $-2.975 * * *$ & -0.197 & $2.404 * * *$ & 0.638 & -0.947 & 0.171 & $1.082 * *$ & 0.205 & -0.0748 & -0.419 & 1.196 \\
\hline & $(0.345)$ & $(0.389)$ & $(0.262)$ & $(0.425)$ & $(0.595)$ & $(0.762)$ & $(0.296)$ & $(0.484)$ & $(0.641)$ & $(0.703)$ & $(0.420)$ & $(0.770)$ \\
\hline $\begin{array}{l}\text { N. } \\
\text { children } \\
13-17\end{array}$ & 0.315 & -0.418 & -0.196 & $1.254 * * *$ & 0.194 & -0.669 & -0.323 & 0.105 & 0.113 & 0.0267 & 0.0823 & 0.942 \\
\hline & $(0.392)$ & $(0.458)$ & $(0.290)$ & $(0.486)$ & $(0.782)$ & $(0.912)$ & $(0.381)$ & $(0.663)$ & $(0.959)$ & $(0.942)$ & $(0.797)$ & $(1.054)$ \\
\hline $\begin{array}{l}\text { N. other } \\
\text { house- } \\
\text { hold } \\
\text { members }\end{array}$ & $1.311^{* * *}$ & 0.615 & -0.441 & -0.274 & 0.654 & 0.763 & -0.374 & -0.618 & $1.956^{* * *}$ & $1.854 * * *$ & $-0.955^{* *}$ & -0.967 \\
\hline & $(0.408)$ & $(0.498)$ & $(0.323)$ & $(0.385)$ & $(0.448)$ & $(0.659)$ & $(0.262)$ & $(0.435)$ & $(0.706)$ & $(0.656)$ & $(0.458)$ & $(0.645)$ \\
\hline $\begin{array}{l}\text { Years of } \\
\text { educa- } \\
\text { tion }\end{array}$ & $0.617 * * *$ & $0.898 * * *$ & $0.101 * *$ & $-0.165 * *$ & 0.0625 & $0.273 * *$ & 0.0702 & $-0.307 * * *$ & 0.255 & $0.527 * * *$ & -0.00247 & $-0.339 * *$ \\
\hline & $(0.0761)$ & $(0.0865)$ & $(0.0484)$ & $(0.0730)$ & $(0.130)$ & $(0.137)$ & $(0.0621)$ & $(0.0920)$ & $(0.160)$ & $(0.155)$ & $(0.143)$ & $(0.147)$ \\
\hline Age & 0.225 & $0.821 * * *$ & 0.00271 & $0.689 * * *$ & -0.0200 & $1.031^{*}$ & -0.164 & -0.0249 & $0.901 * *$ & 0.0835 & -0.121 & 0.434 \\
\hline & $(0.149)$ & $(0.206)$ & $(0.0952)$ & $(0.198)$ & $(0.405)$ & $(0.537)$ & $(0.216)$ & $(0.324)$ & $(0.350)$ & $(0.341)$ & $(0.181)$ & $(0.342)$ \\
\hline $\begin{array}{l}\text { Age } \\
\text { squared }\end{array}$ & $-0.399^{* * *}$ & $-1.102^{* * *}$ & 0.0174 & $-0.702 * * *$ & -0.0714 & $-1.231^{*}$ & 0.232 & 0.0900 & $-1.173^{* * *}$ & -0.253 & 0.124 & -0.388 \\
\hline & $(0.166)$ & $(0.250)$ & $(0.103)$ & $(0.242)$ & $(0.458)$ & $(0.643)$ & $(0.243)$ & $(0.393)$ & $(0.376)$ & $(0.377)$ & $(0.178)$ & $(0.370)$ \\
\hline $\begin{array}{l}\text { Indige- } \\
\text { nous }\end{array}$ & - & - & - & - & 1.553 & $4.048 * *$ & $1.761 * *$ & -0.508 & -1.230 & 0.731 & -0.0483 & -1.117 \\
\hline & - & - & - & - & $(1.300)$ & (1.668) & $(0.744)$ & $(1.107)$ & $(3.947)$ & $(3.535)$ & $(1.213)$ & (1.895) \\
\hline $\begin{array}{l}\text { Urban } \\
\text { area* }\end{array}$ & $3.465^{* * *}$ & $3.975 * * *$ & $-2.172 * * *$ & $-6.392 * * *$ & $8.123^{* *}$ & $9.054 * *$ & $-5.221 * *$ & $-13.58^{* * * *}$ & $4.533 * * *$ & 2.150 & $-2.601 * * *$ & $-5.556^{* * * *}$ \\
\hline & $(0.928)$ & $(1.066)$ & $(0.693)$ & $(0.922)$ & (3.654) & $(4.060)$ & $(2.072)$ & (2.943) & $(1.531)$ & $(1.492)$ & $(0.958)$ & (1.598) \\
\hline Region 1 & $4.358^{* * *}$ & $5.423 * * *$ & $-1.040^{*}$ & $-2.686 * * * *$ & $-5.333^{* * * *}$ & -1.799 & 0.627 & $3.664 * * *$ & 0.960 & $-7.887^{* * *}$ & 0.858 & $5.573^{* *}$ \\
\hline & $(0.850)$ & $(0.856)$ & $(0.549)$ & $(0.853)$ & $(1.377)$ & (1.853) & $(0.669)$ & (1.165) & (2.298) & $(2.146)$ & $(1.262)$ & $(2.206)$ \\
\hline Region 2 & -0.0871 & $1.864 * *$ & -0.488 & $1.502^{*}$ & $-5.044 * * * *$ & -1.077 & $1.680 * *$ & $4.167 * * *$ & -1.475 & $-7.284 * * *$ & 0.666 & 0.218 \\
\hline & $(0.822)$ & $(0.827)$ & $(0.566)$ & $(0.814)$ & $(1.396)$ & $(1.904)$ & $(0.726)$ & $(1.175)$ & $(1.971)$ & $(1.919)$ & $(0.906)$ & $(1.772)$ \\
\hline
\end{tabular}


Table 2. (continued). SUR estimates on the time devoted to paid work and unpaid work (couples)

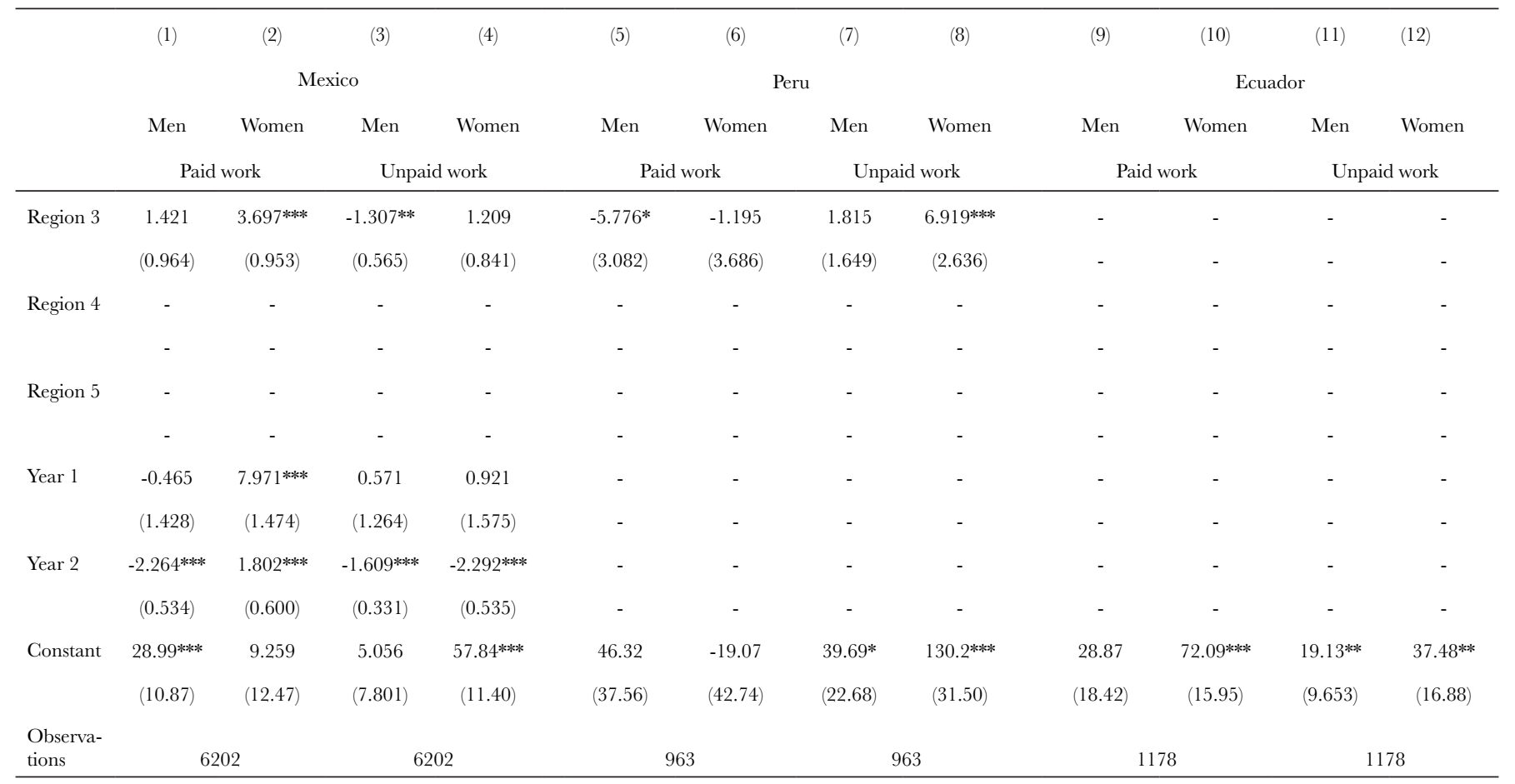

Notes: Data sources are time-use surveys from Mexico (2002,2009,2014), Peru (2010), Ecuador (2012), Colombia $(2012,2017)$ and Chile (2015). The sample is restricted to heterosexual couples who are not students or retired. *Weekly hours for paid and unpaid work are considered for Mexico, Peru, Ecuador, and Chile and daily hours for paid and unpaid work are considered for Colombia. For Mexico, region 1 represents the Centre region, region 2 represents the West-centre region, region 3 represents the North region and region 4 represents the Southsoutheast region. For Peru, region 1 represents the Rest of the Coast region, region 2 represents the Sierra region, region 3 represents the Selva region and region 4 represents Lima region. For Ecuador, region 1 represents the Sierra region, region 2 represents the Costa region and region 3 represents the Amazon region. For Colombia, region 1 represents the Atlantic region, region 2 represents the Central region, region 3 represents the Eastern region, region 4 represents the Pacific Region, region 5 represents Bogota region and region 6 represents San Andres region. For Chile, region 1 represents Norte Grande region, region 2 represents Norte Chico region, region 3 represents Central Nucleus region, region 4 represents Concepción and La Frontera regions, region 5 represents Region of the Lakes, and region 6 represents Region of the Channels. Robust standard errors in parentheses *** $\mathrm{p}<0.01, * * \mathrm{p}<0.05, * \mathrm{p}<0.1$ 
Table 3. SUR estimates on the time devoted to paid work and unpaid work (couples)

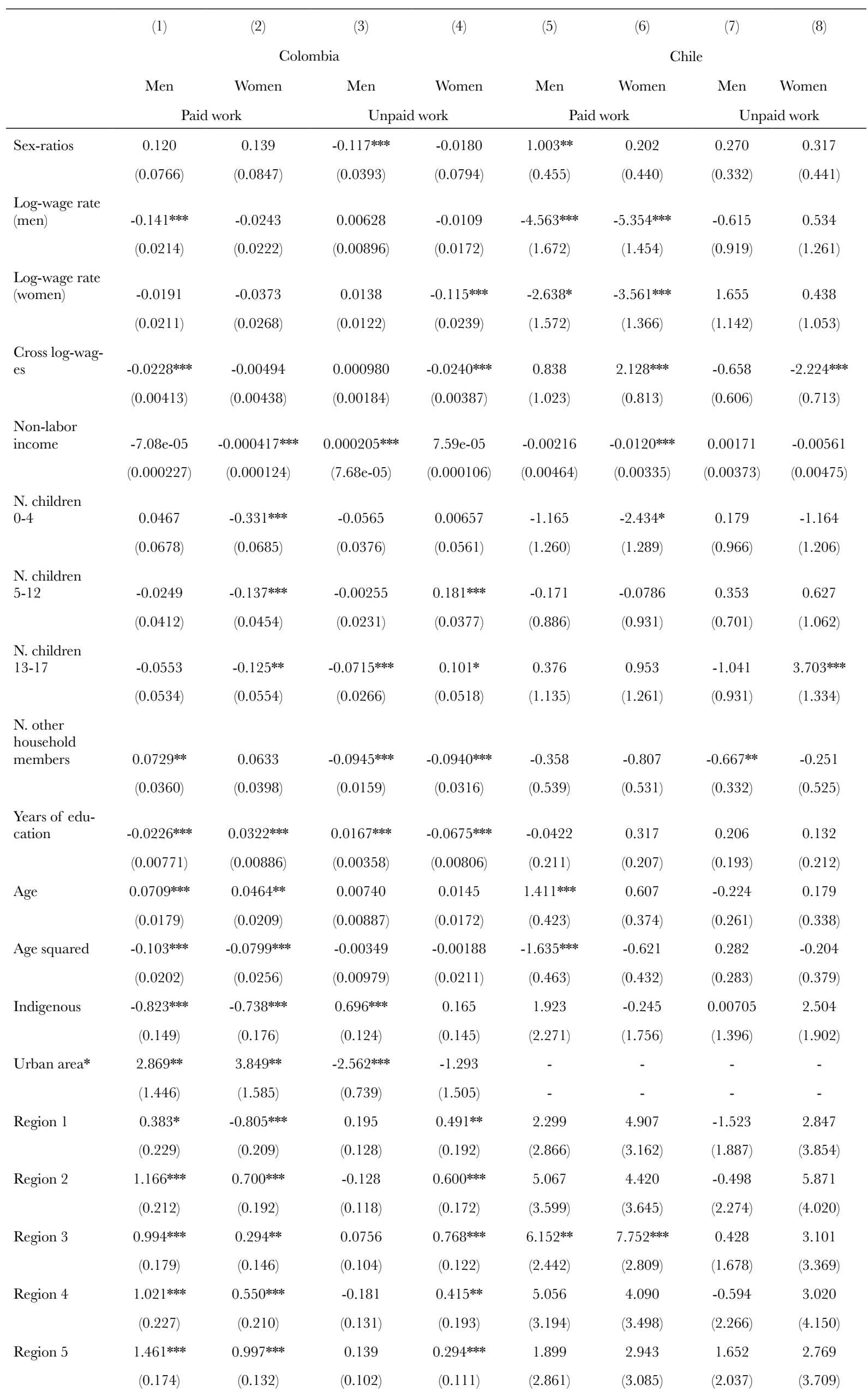


Table 3. (continued). SUR estimates on the time devoted to paid work and unpaid work (couples)

\begin{tabular}{|c|c|c|c|c|c|c|c|c|}
\hline & (1) & (2) & (3) & (4) & (5) & (6) & (7) & (8) \\
\hline & \multicolumn{4}{|c|}{ Colombia } & \multicolumn{4}{|c|}{ Chile } \\
\hline & Men & Women & Men & Women & Men & Women & Men & Women \\
\hline & \multicolumn{2}{|c|}{ Paid work } & \multicolumn{2}{|c|}{ Unpaid work } & \multicolumn{2}{|c|}{ Paid work } & \multicolumn{2}{|c|}{ Unpaid work } \\
\hline \multirow[t]{2}{*}{ Year 1} & 0.0818 & 0.00988 & $-0.105^{* * * *}$ & -0.0672 & - & - & - & - \\
\hline & $(0.0607)$ & $(0.0675)$ & $(0.0316)$ & $(0.0600)$ & - & - & - & - \\
\hline \multirow[t]{2}{*}{ Year 2} & - & - & - & - & - & - & - & - \\
\hline & - & - & - & - & - & - & - & - \\
\hline \multirow[t]{2}{*}{ Constant } & -6.636 & -10.16 & $13.71^{* * * *}$ & 5.481 & -65.05 & 11.41 & -10.68 & -8.230 \\
\hline & (8.587) & $(9.515)$ & $(4.415)$ & $(8.980)$ & $(46.15)$ & (43.96) & $(32.60)$ & $(43.85)$ \\
\hline Observations & \multicolumn{2}{|c|}{9842} & \multicolumn{2}{|c|}{9842} & \multicolumn{2}{|c|}{1215} & \multicolumn{2}{|c|}{1215} \\
\hline
\end{tabular}

Notes: Data sources are time-use surveys from Mexico (2002,2009,2014), Peru (2010), Ecuador (2012), Colombia $(2012,2017)$ and Chile (2015). The sample is restricted to heterosexual couples who are not students or retired. *Weekly hours for paid and unpaid work are considered for Mexico, Peru, Ecuador, and Chile and daily hours for paid and unpaid work are considered for Colombia. For Mexico, region 1 represents the Centre region, region 2 represents the West-centre region, region 3 represents the North region and region 4 represents the Southsoutheast region. For Peru, region 1 represents the Rest of the Coast region, region 2 represents the Sierra region, region 3 represents the Selva region and region 4 represents Lima region. For Ecuador, region 1 represents the Sierra region, region 2 represents the Costa region and region 3 represents the Amazon region. For Colombia, region 1 represents the Atlantic region, region 2 represents the Central region, region 3 represents the Eastern region, region 4 represents the Pacific Region, region 5 represents Bogota region and region 6 represents San Andres region. For Chile, region 1 represents Norte Grande region, region 2 represents Norte Chico region, region 3 represents Central Nucleus region, region 4 represents Concepción and La Frontera regions, region 5 represents Region of the Lakes, and region 6 represents Region of the Channels. Robust standard errors in parentheses *** $\mathrm{p}<0.01, * * \mathrm{p}<0.05, * \mathrm{p}<0.1$

In Chile (columns 5 and 6 in Table 3), the log of men's hourly wage is negatively related to the time devoted by men and women to paid work. The log of women's hourly wage is negatively related to the time devoted by men and women to paid work, with these results being statistically significant at standard levels. ${ }^{21}$ The results for women in Mexico, Peru, and Ecuador are in line with Campaña, Gimenez Nadal and Molina (2018), in that there may be social norms in the country that limit the labor participation of women, in such a way that the spouse's salary has no effect on female labor supply. In these countries, social norms indicate that women must take responsibility for family obligations, so their labor supply is inelastic with respect to factors that include the spouse's salary.

Regarding unpaid work, we find in Mexico (column 4 in Table 2), Ecuador (column 12 in Table 2), and Colombia (column 4 in Table 3), that the log of women's hourly wage negatively influences the time devoted by women to unpaid work. For non-labor income, we observe non-labor household income influences negatively the time devoted by women to paid work in Colombia (column 2 in Table 3) and Chile (column 6 in Table 3) and influences positively the time devoted by men to unpaid work in Ecuador (column 11 in Table 2) and Colombia (column 3 in Table 3).

Other factors affect time allocation decisions. For example, the presence of children is negatively related to the time devoted by women to paid work in Mexico (column 2 in Table 2, age

21 Table D1 in the Appendix shows quartiles of income per hour worked (from the lowest to the highest income). We observe that, for the five countries, men in quartile 1 (lowest income) devote, relative to men in quartile 4 (highest income), 7.7 more hours to paid work, and women in quartile 1 (lowest income) devote, relative to women in quartile 4 (highest income) 5.19 more hours per week to paid work. These results indicate that the negative relationship between women's hourly wage and market work hours is not an artifact of the estimated models, but a real phenomenon. Regarding the negative relationship between the $(\log )$ hourly wage and the time dedicated by both spouses to paid work in Chile, the results are similar to the research carried out by Chiappori, Fortin and Lacroix (2002) for men in couples in the United States, and also to the research conducted by Rapoport, Sofer and Solaz (2011) or men and women in couples in France. 
range 0-4 and 5-12), Peru (column 6 in Table 2, age range 0-4), Colombia (column 2 in Table 3 , age range 0-4, 5-12 and 13-17), and Chile (column 6 in Table 3, age range 0-4), The presence of children is positively related to the time devoted by women to unpaid work in Mexico (column 4 in Table 2, age range 0-4, 5-12 and 13-17), Peru (column 8 in Table 2, age range 0-4 and 5-12), Ecuador (column 12 in Table 2, age range 0-4), Colombia (column 4 in Table 3, age range 5-12 and 13-17), and Chile (column 8 in Table 3, age range 13-17). The fact that there are more members in the household (e.g., grandparents, uncles...) is positively related to the time devoted to paid work by men and women in Ecuador (column 9 and 10 in Table 2), men in Mexico (column 1 in Table 2) and men in Colombia (column 1 in Table 3). Regarding unpaid work, the presence of other household members is negatively related to the time devoted to unpaid work by men in Ecuador (column 11 in Table 2), men and women in Colombia (column 3 and 4 in Table 3) and men in Chile (column 7 in Table 3).

Regarding years of education, this variable is positively related to the time devoted by men and women to paid work in Mexico (column 1 and 2 in Table 2) and by women in Peru (column 6 in Table 2), Ecuador (column 10 in Table 2) and Colombia (column 2 in Table 3). These results are similar to those presented by Gimenez Nadal and Sevilla (2012) for European countries. more years of education leads to more time in paid work by individuals. Being indigenous means that men and women dedicate less time to paid work (column 1 and 2 in Table 3) and men dedicate more time to unpaid work (column 3 in Table 3 ) in Colombia, and women dedicate more time to paid work (column 6 in Table 2) and men dedicate more time to unpaid work (column 7 in Table 2) in Peru, compared to non-indigenous people. As for living in an urban area, in Mexico (column 1 and 2 in Table 2), Peru (column 5 and 6 in Table 3) and Colombia (column 1 and 2 in Table 3), men and women spend more time in paid work. In Ecuador (column 9 in Table 2) men in urban areas spend more time in paid work. Living in an urban area means that men and women spend less time in unpaid work in Mexico (column 1 and 2 in Table 2), Peru (column 5 and 6 in Table 2), and Ecuador (column 9 and 10 in Table 2), and men spend less time in unpaid work in Colombia (column 1 and 2 in Table 3).

\section{Conclusions}

In this paper, we analyze the time men and women in couples devote to paid and unpaid work in five Latin American countries, with particular attention to the effect of sex-ratios in the time devoted to these activities. We use the time use surveys from Mexico (2002, 2009, 2014), Peru (2010) Ecuador (2012), Colombia (2012 and 2017) and Chile (2015), employing a SUR linear model on the time devoted to paid and unpaid work for our econometric estimates. Our main results show that in Ecuador the sex-ratio negatively influences the time devoted by women to paid work, and positively influences the time devoted by men to paid work in Mexico and Chile. In Colombia, we find the sex-ratio negatively influences the time devoted by men to unpaid work, and decreases the time devoted by women to unpaid work in Mexico and Peru.

The observed cross-country differences in the relationship between sex ratios, on the one hand, and the time devoted to paid and unpaid work, on the other, may be due to variations in the relationship between sex ratios and gender roles (what women should and should not do in society), institutional factors (differences in the tax schemes affecting second earners in households), or unobserved preferences that determine education and rural location and, in turn, affect sex ratios. The analysis of such cross-country differences is complex, and is beyond the scope of this manuscript, so we leave this issue for further research. Furthermore, such cross-country differences may lead us to a novel insight based on the current models of economic decisions in a marriage, and these models may be reformulated (or new ones proposed) to explain cross-country differences in the relationship between sex ratios and labor in couples. 
Regarding other factors, in Mexico, Peru, Colombia, and Chile, we observe that the presence of younger children negatively influences the time devoted by women to paid work, so it is recommended that policy makers work to provide households with young children access to formal childcare services. Hallman, Quisumbing, Ruel and de la Briere (2005), Contreras, Puentes and Bravo (2012) and Mateo Díaz and Rodriguez-Chamussy, (2016), all for Latin American countries, show the benefits of formal childcare services and their positive effect on mothers' working hours.

One limitation of our analysis is that our data is a cross-section of individuals and does not allow us to identify differences in the time devoted to work, net of (permanent) individual heterogeneity in preferences and characteristics. At present, there are no panels of time-use surveys available, and we leave this issue, also, for future research.

\section{Disclosure statement}

No potential conflict of interest was reported by the authors.

\section{Acknowledgements}

This paper has benefited from funding from the Spanish Ministry of Economics (Project ECO2012-34828) and the pre-doctoral grant, awarded by the Government of Aragon in Spain, co-financed by the European Social Fund (BOA, 2 December 2014). We sincerely appreciate the assistance of Jaime Celi Zhingre $\dagger$ for this paper.

\section{References}

Aguiar, M., and Hurst, E. (2007). Measuring trends in leisure: The allocation of time over five decades. The Quarterly Journal of Economics, 122(3), 969-1006. https://doi.org/10.1162/ qjec.122.3.969

Aguilar, M., Espinosa, I., and Argeñal, J. (2004). Uso del Tiempo de los y las nicaragüenses. Programa MECOVI. Managua: Instituto Nacional de Estadísticas y Censos. http://www. sidalc.net/cgi-bin/wxis.exe/?IsisScript=FAONI.xis\&method=post\&formato=2\&canti$\underline{\mathrm{dad}=1 \& \text { expresion }=\mathrm{mfn}=000394}$

Angrist, J. (2002). How do sex-ratios affect marriage and labor markets? Evidence from America's second generation. The Quarterly Journal of Economics, 117(3), 997-1038. https:// doi.org/10.1162/003355302760193940

Apps, P., and Rees, R. (2005). Gender, time use, and public policy over the life cycle. Oxford Review of Economic Policy, 21(3), 439-461. https://doi.org/10.1093/oxrep/gri025

Becker, G. S. (1965). A Theory of the Allocation of Time. The economic journal, 75(299), 493517. https://doi.org/10.2307/2228949

Becker, G. S. (1973). A theory of marriage: Part I. Journal of Political economy, 81(4), 813-846. https://doi.org/10.1086/260084

Becker, G. S. (1991). A Treatise on the Family. Cambridge, Mass.: Harvard Univ. Press. https:// www.hup.harvard.edu/catalog.php?isbn $=9780674906990$

Bianchi, S. M. (2000). Maternal employment and time with children: Dramatic change or surprising continuity? Demography, 37 (4), 401-414. https://doi.org/10.1353/dem.2000.0001

Calero, A., Dellavalle, R., and Zanino, C. (2016). Care Economy in Argentina: Some Results Based on the Time Use Survey. MPRA Paper No. 72820, Munich Personal RePEc Archive, Munich, Germany. https://core.ac.uk/download/pdf/213986496.pdf 
Campaña, J. C., Gimenez-Nadal, J. I., and Molina, J. A. (2017). Increasing the Human Capital of Children in Latin American Countries: The Role of Parents' Time in Child care. The Journal of Development Studies, 53 (6), 805-825. https://doi.org/10.1080/00220388.20 $\underline{16.1208179}$

Campaña, J. C., Giménez-Nadal, J. I., and Molina, J. A. (2018). Gender norms and the gendered distribution of total work in Latin American households. Feminist Economics, 24(1), 35-62. https://doi.org/10.1080/13545701.2017.1390320

Campaña, J. C., Giménez-Nadal, J. I., and Molina, J. A. (2020). Self-employed and Employed Mothers in Latin American Families: Are There Differences in Paid Work, Unpaid Work, and Child Care? Journal of Family and Economic Issues, 1-18. https://doi.org/10.1007/s10834-020-09660-5

Canelas, C., and Salazar, S. (2014). Gender and ethnic inequalities in LAC countries. IZA Journal of Labor and Development, 3(1), 18. https://doi.org/10.1186/2193-9020-3-18

CEPAL (2014) http://repositorio.cepal.org/bitstream/11362/37626/5/anexo estadistico2014 es.zip

Chiappori, P.-A. (1988). Rational household labor supply. Econometrica, 56(1), 63-90. https:// doi.org/10.2307/1911842

Chiappori, P.-A. (1992). Collective labor supply and welfare. Journal of Political Economy, 100(3), 437-467. https://doi.org/10.1086/261825

Chiappori, P. A., Fortin, B., and Lacroix, G. (2002). Marriage market, divorce legislation, and household labor supply. Journal of political Economy, 110(1), 37-72. https://doi. org/10.1086/324385

Connelly, R., and Kimmel, J. (2009). Spousal influences on parents' non-market time choices. Review of Economics of the Household, 7(4), 361-394. https://doi.org/10.1007/s11150009-9060-y

Contreras, D., E. Puentes, and D. Bravo. 2012. Female Labor Supply and Child Care Supply in Chile. Working Paper SDT 370, Department of Economics, University of Chile, Santiago. https://econ.uchile.cl/uploads/publicacion/93fc99073cf6830a16930b85e473c49df8b0d854.pdf

Cox, O. C. (1940). Sex-ratios and marital status among Negroes. American sociological review, 5(6), 937-947. https://doi.org/10.2307/2084528

DANE (2012) Encuesta Nacional de Uso del Tiempo, Colombia - ENUT (2012-2013) http:// microdatos.dane.gov.co/index.php/catalog/214/study-description

DANE (2017) Encuesta Nacional de Uso del Tiempo, Colombia - ENUT (2016-2017) https:// www.dane.gov.co/index.php/estadisticas-por-tema/pobreza-y-condiciones-de-vida/encuesta-nacional-del-uso-del-tiempo-enut

DANE (2020) Estimaciones y proyecciones de la población

https://www.dane.gov.co/index.php/estadisticas-por-tema/demografia-y-poblacion/censo-general-2005-1\#proyecciones-de-poblacion-linea-base-2005

Du, Q., and Wei, S. J. (2013). A theory of the competitive saving motive. Journal of International Economics, 91(2), 275-289. https://doi.org/10.1016/j.jinteco.2013.09.003

Easterlin, R. A. (1968). The American baby boom in historical perspective. In Population, labor force, and long swings in economic growth: the American experience (pp. 77-110). NBER. https://www.nber.org/system/files/chapters/c1119/c1119.pdf 
ECLAC, N. (2015). Classification of time use activities for Latin America and the Caribbean (CAUTAL). Santiago: ECLAC, 2015. LC / W. 679 https://www.cepal.org/en/publications/40170-classification-time-use-activities-latin-america-and-caribbean-cautal

Esplen, E. (2009). Gender and Care: Overview Report. Brighton: Institute of Development Studies: Overview Report. Brighton: Institute of Development Studies https://core.ac.uk/ download/pdf/43666812.pdf

Esquivel, V. (2010). Lessons from the Buenos Aires Time-Use Survey: A Methodological Assessment. In Unpaid Work and the Economy (pp. 181-214). Palgrave Macmillan UK. http:// www.atususers.umd.edu/wip2/papers i2007/Esquivelv.pdf

Esquivel, V., Budlender, D., Folbre, N., and Hirway, I. (2008). Explorations: Time-use surveys in the south. Feminist Economics, 14(3), 107-152. https://doi.org/10.1080/13545700802075135

Floro, M. S., and Pichetpongsa, A. (2010). Gender, work intensity, and well-being of Thai home-based workers. Feminist Economics, 16(3), 5-44. https://doi.org/10.1080/135457 $\underline{01.2010 .499657}$

Folbre, N. (2006). Measuring care: Gender, empowerment, and the care economy. Journal of human development, 7(2), 183-199. https://doi.org/10.1080/14649880600768512

Folbre, N., Yoon, J., Finnoff, K., and Fuligni, A. S. (2005). By what measure? Family time devoted to children in the United States. Demography, 42(2), 373-390. https://doi.org/10.1353/ dem.2005.0013

Foster, G. and Kalenkoski, G. (2013) Tobit or OLS? An empirical evaluation under different diary window lengths, Applied Economics, 45, 2994-3010. https://doi.org/10.1080/000 $\underline{36846.2012 .690852}$

Frazis, H., and Stewart, J. (2012). How to think about time-use data: what inferences can we make about long-and short-run time use from time diaries? Annals of Economics and Statistics/ANNALES D'ÉCONOMIE ET DE STATISTIQUE, 231-245. https://doi. org/10.2307/23646463

Gammage, S. (2010). Time pressed and time poor: unpaid household work in Guatemala. Feminist Economics, 16(3), 79-1 12. https://doi.org/10.1080/13545701.2010.498571

Gershuny, J. (2000) Changing Times: Work and Leisure in post-industrial Society. Oxford: Oxford University Press. https://www.jstor.org/stable/3559512

Gimenez-Nadal, J. I., and Molina, J. A. (2013). Parents' education as a determinant of educational childcare time. Journal of Population Economics, 26(2), 719-749. https://doi.org/10.1007/s00148-012-0443-7

Gimenez-Nadal,J.I, and J. A. Molina (2015). Health status and the allocation of time: cross-country evidence in Europe. Economic Modelling, 46(2): 188-203. https://doi.org/10.1016/j. econmod.2014.12.034

Gimenez-Nadal, J. I., and Sevilla, A. (2012) Trends in time allocation: a cross-country analysis. European Economic Review 56, 1338-59 https://doi.org/10.1016/j.euroecorev.2012.02.011

Glick, P. C., Beresford, J. C., and Heer, D. M. (1963). Family formation and family composition: Trends and prospects. In Sourcebook in marriage and the family, ed. Marvin.B. Sussman. Boston: Houghton Mifflin.

Goldman, N. (1977). The marriage market: Supply and demand of potential spouses in the United States. Cambridge, Mass.: Harvard University, Center for Population Studies. 
Goldman, N., Westoff, C. F., and Hammerslough, C. (1984). Demography of the marriage market in the United States. Population Index, 5-25. https://doi.org/10.2307/2736903

Grossbard-Shechtman, A. (1984). A theory of allocation of time in markets for labour and marriage. The Economic Journal, 94(376), 863-882. https://doi.org/10.2307/2232300

Grossbard-Shechtman, S. (2003). Marriage and the Economy. Marriage and Economy: Theory and Evidence from Advanced Industrial Societies, 1-34. https://doi.org/10.1017/CBO9780511615863

Grossbard, S. (2014). The marriage motive: A price theory of marriage: How marriage markets affect employment, consumption, and savings. Springer. https://doi.org/10.1007/978-14614-1623-4

Grossbard, S. and Amuedo-Dorantes, C. (2007). Cohort-level sex-ratios effects on women's labor force participation. Review of Economics of the Household, 5, 249-278. https://doi. org/10.1007/s11150-007-9014-1

Groves, E. R., and Ogburn, W. F. (1928). American marriage and family relationships. New York: H. Holt.

Guryan, J., Hurst, E., and Kearney, M. S. (2008). Parental education and parental time with children. The Journal of Economic Perspectives, 22(3), 23-46. https://doi.org/10.1257/ jep.22.3.23

Hallman, K., Quisumbing, A. R., Ruel, M., and de la Briere, B. (2005). Mothers' work and child care: findings from the urban slums of Guatemala City. Economic development and cultural change, 53(4), 855-885. https://doi.org/10.1086/427458

Henry, L. (1975). Schéma d'évolution des mariages après de grandes variations des naissances. Population (french edition), 759-780. https://doi.org/10.2307/1530481

INE (2015). Encuesta Nacional sobre Uso del Tiempo: Documento metodológico. ENUT 2015. https://historico-amu.ine.cl/enut/files/documentacion/documento metodologico ENUT.pdf

INE (2021) ESTIMACIONES Y PROYEGCIONES DE LA POBLACIÓN DE CHILE 20022035 http://www.ine.cl/docs/default-source/proyecciones-de-poblacion/cuadros-estadisticos/base-2017/ine estimaciones-y-proyecciones-2002-2035 base-2017 region area tabulados.xlsx?sfvrsn $=$ e9bd6edf 6

INEC. (2012). Encuesta Específica de Uso del Tiempo, Ecuador 2012. https://www.ecuadorencifras.gob.ec/documentos/web-inec/Uso Tiempo/Metodologia EUT 2012.pdf

INEG (2021). Proyección Provincial Urbano-Rural, Grupos de Edades y Sexo 2010-2020 https://sni.gob.ec/proyecciones-y-estudios-demograficos

INEGI. (2002). Encuesta Nacional sobre uso del Tiempo, Mexico 2002. https:/ / www.inegi.org. $\mathrm{mx} /$ programas/enut/2002/

INEGI. (2009). Encuesta Nacional sobre uso del Tiempo, Mexico 2009. https:/ /www.inegi.org. $\underline{\mathrm{mx} / \mathrm{rnm} / \mathrm{index} . \mathrm{php} / \mathrm{catalog} / 12}$

INEGI. (2014). Encuesta Nacional sobre uso del Tiempo, Mexico 2014. https:/ /www.inegi.org. $\underline{\mathrm{mx} / \mathrm{prog} \text { ramas/enut/2014/ }}$

INEGI (2021). Censo y conteos de población y vivienda https://www.inegi.org.mx/programas/ ccpv/2000/

INEI. (2010). Encuesta Nacional sobre uso del Tiempo, Peru 2010. https://www.inei.gob.pe/ media/MenuRecursivo/publicaciones digitales/Est/Lib0960/Libro.pdf 
INEI (2007). Censos Nacionales 2007 http://censos.inei.gob.pe/cpv2007/tabulados/\#

Kahneman, D and Krueger, A. B. (2006) Developments in the measurement of subjective well-being. Journal of Economic Perspectives, 20, 3-24. https://doi. org/10.1257/089533006776526030

Kalenkoski, C. M., and Foster, G. (2015). Measuring the relative productivity of multitasking to sole-tasking in household production: experimental evidence. Applied Economics, 47(18), 1847-1862. https://doi.org/10.1080/00036846.2014.1000526

Kalenkoski, C. M., Ribar, D. G., and Stratton, L. S. (2005). Parental child care in single-parent, cohabiting, and married-couple families: Time-diary evidence from the United Kingdom. American Economic Review, 95(2), 194-198. https://doi. org/10.1257/000282805774670176

Kimmel,J., and Connelly, R. (2007). Mothers' time choices caregiving, leisure, home production, and paid work. Journal of Human Resources, 42(3), 643-681 https://doi.org/10.3368/ jhr.XLII.3.643

Krueger, A. B. (2007) Are we having more fun yet? Categorizing and evaluating changes in time allocation. Brooking Papers on Economic Activity, 2, 193-217. https://www.jstor.org/ stable/27561605

Lundberg, S., and Pollak, R. A. (1993). Separate spheres bargaining and the marriage market. Journal of Political Economy, 101 (6), 988-1010 https://doi.org/10.1086/261912

Mateo Díaz, M., and Rodriguez-Chamussy, L. (2016). Cashing in on Education: Women, Childcare, and Prosperity in Latin America and the Caribbean. World Bank Publications. https://elibrary.worldbank.org/doi/abs/10.1596/978-1-4648-0902-6

Medeiros, M., Osório, R. G., and Costa, J. (2010). Gender inequalities in allocating time to paid and unpaid work: evidence from Bolivia. In Unpaid Work and the Economy (pp. 58-75). Palgrave Macmillan, London. https://doi.org/10.1057/9780230250550 3

Milosavljevic, V. (2007). Estadísticas para la equidad de género: Magnitudes y tendencias en América Latina [Statistics for gender equity: Magnitudes and trends in Latin America]. Santiago, Chile: Naciones Unidas https://repositorio.cepal.org/handle/11362/27843

Molina, J. A., Gimenez-Nadal, J. I., and Velilla, J. (2018). Intertemporal Labor Supply: A Household Collective Approach. IZA DP No. 11276 https://ssrn.com/abstract=3111149

Mroz, T. A. (1987). The sensitivity of an empirical model of married women's hours of work to economic and statistical assumptions. Econometrica: Journal of the econometric society, 765-799.https://doi.org/10.2307/1911029

Newman, C. (2002). Gender, time use, and change: the impact of the cut flower industry in Ecuador. the world bank economic review, 16(3), 375-395. https://doi.org/10.1093/wber/ $\underline{\text { lhf006 }}$

Rapoport, B., Sofer, G., and Solaz, A. (2011). Household production in a collective model: some new results. Journal of Population Economics, 24(1), 23-45. https://doi.org/10.1007/ $\underline{\text { s00148-010-0308-x }}$

Sevilla-Sanz, A., Gimenez-Nadal, J. I., and Fernández, C. (2010). Gender roles and the division of unpaid work in Spanish households. Feminist Economics, 16(4), 137-184. https://doi.or $\mathrm{g} / 10.1080 / 13545701.2010 .531197$

Schoen, R. (1983). Measuring the tightness of a marriage squeeze. Demography, 20(1), 61-78. https://doi.org/10.2307/2060901 
United Nations (2015). The World's Women 2015: Trends and Statistics. New York: United Nations, Department of Economic and Social Affairs, Statistics Division. Sales No. E.15. XVII.8. https://unstats.un.org/unsd/gender/downloads/worldswomen2015 report.pdf

World Bank. (2021) https://data.worldbank.org/indicator/SL.TLF.CACT.FE.ZS

Wei, S. J., and Zhang, X. (2011). The competitive saving motive: Evidence from rising sex-ratios and savings rates in China. Journal of political Economy, 119(3), 511-5 https://doi. $\underline{\operatorname{org} / 10.1086 / 660887}$

\section{APPENDIX.}

Table A1. Classification of activities (CAUTAL)

Major divisions (one digit) and divisions (two digits)

\begin{tabular}{ll}
\hline Paid work & Employment and related activities \\
11 Employment \\
14 Commuting to and from work \\
\hline 2. Own-use goods production \\
21 Primary own-use activities \\
22 Non-primary own-use activities (excluding construction) \\
23 Construction for own final use \\
3. Unpaid domestic work for own household \\
31 Food preparation and serving \\
32 Cleaning of the home \\
33 Cleaning and care of clothes and footwear \\
34 Maintenance and minor repairs for own household \\
35 Household management \\
36 Shopping for the household (including travel) \\
37 Pets and plants care \\
5. Unpaid work for other households or the community and volunteering \\
51 Unpaid work for other households (excluding unpaid care of people from other households) \\
52 Unpaid work for the community \\
53 Volunteer work at non-profit institutions \\
\end{tabular}

Notes: Classification of Time-Use Activities for Latin America and the Caribbean (CAUTAL). See http:// repositorio.cepal.org/bitstream/handle/11362/40170/1/S1600307 en.pdf for a greater division of activities. (Divisions, groups (three digits) and subgroups (four digits)).

Source: Time Use Survey of Mexico (2002, 2009, 2014), Peru (2010), Ecuador (2012), Colombia (2012, 2017) and Chile (2015)

Table B1. SUR estimates on the participation of couples in the labor market

\begin{tabular}{|c|c|c|c|c|c|c|c|c|c|c|}
\hline & (1) & (2) & (3) & (4) & (5) & (6) & (7) & (8) & (9) & (10) \\
\hline & \multicolumn{2}{|c|}{ Mexico } & \multicolumn{2}{|c|}{ Peru } & \multicolumn{2}{|c|}{ Ecuador } & \multicolumn{2}{|c|}{ Colombia } & \multicolumn{2}{|c|}{ Chile } \\
\hline & Men & Women & Men & Women & Men & Women & Men & Women & Men & Women \\
\hline & \multicolumn{2}{|c|}{ Paid work } & \multicolumn{2}{|c|}{ Paid work } & \multicolumn{2}{|c|}{ Paid work } & \multicolumn{2}{|c|}{ Paid work } & \multicolumn{2}{|c|}{ Paid work } \\
\hline \multirow[t]{2}{*}{ Sex-ratios } & $0.00199 * *$ & $0.00337 * *$ & -0.000508 & -0.00610 & -0.000324 & $-0.00765^{* * * *}$ & -0.00200 & $-0.0242 * * *$ & -0.00922 & -0.00270 \\
\hline & $(0.000808)$ & $(0.00148)$ & $(0.00213)$ & $(0.00649)$ & $(0.000560)$ & $(0.00188)$ & $(0.00462)$ & $(0.00405)$ & $(0.00574)$ & $(0.00692)$ \\
\hline Non-labor income & $-2.02 \mathrm{e}-05 * *$ & 8.86e-06 & - & - & $-2.87 \mathrm{e}-05$ & $1.83 \mathrm{e}-05$ & $-0.000149 * * *$ & $-7.08 \mathrm{e}-05 * * *$ & $-5.54 \mathrm{e}-05$ & $-0.000138 *$ \\
\hline
\end{tabular}


Table B1. (continued). SUR estimates on the participation of couples in the labor market

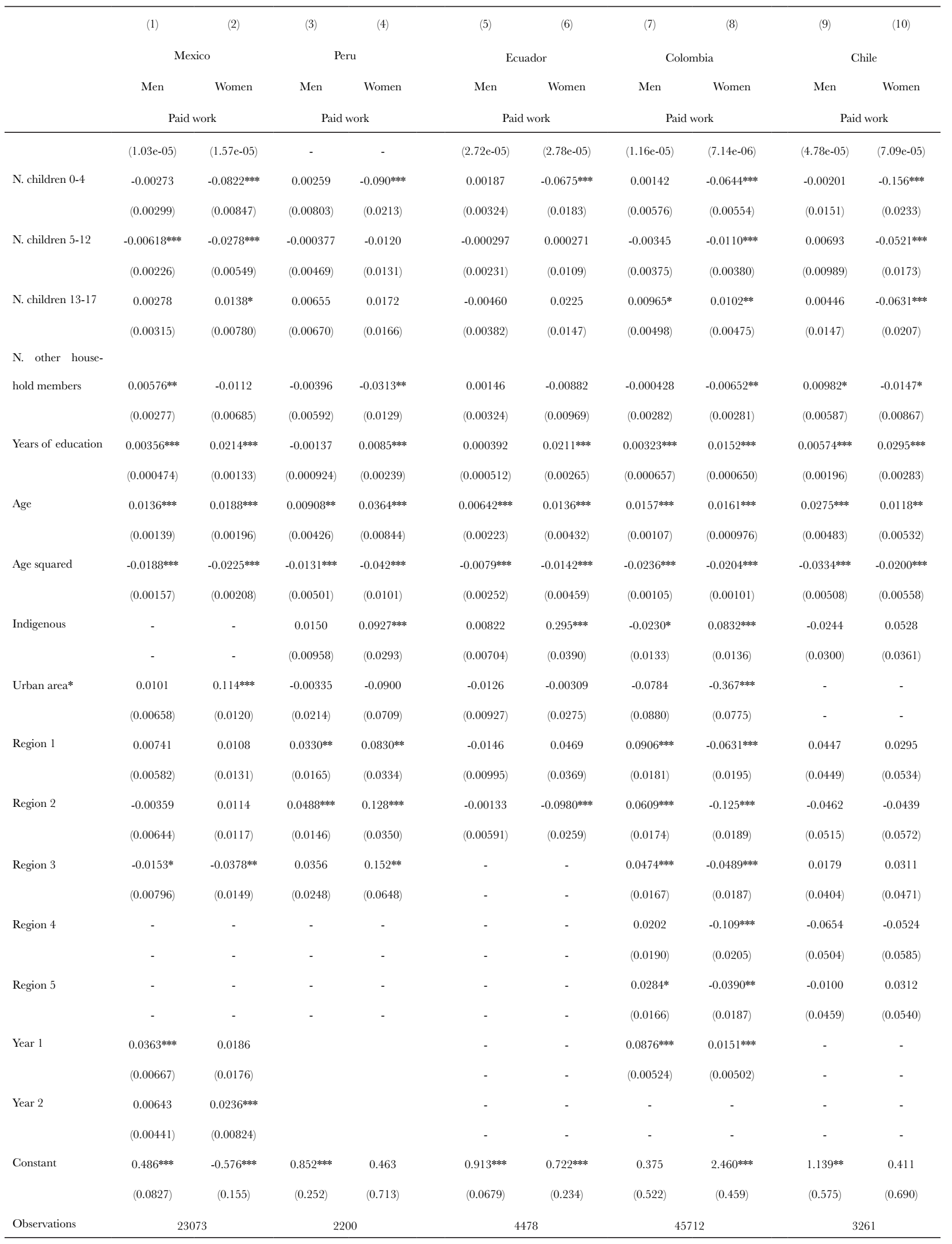

Notes: Data sources are time-use surveys from Mexico (2002,2009,2014), Peru (2010), Ecuador (2012), Colombia $(2012,2017)$ and Chile (2015). The sample is restricted to heterosexual couples who are not students or retired. *Weekly hours for paid and unpaid work are considered for Mexico, Peru, Ecuador, and Chile and daily hours for paid and unpaid work are considered for Colombia. For Mexico, region 1 represents the Centre region, region 2 represents the West-centre region, region 3 represents the North region and region 4 represents the Southsoutheast region. For Peru, region 1 represents the Rest of the Coast region, region 2 represents the Sierra region, region 3 represents the Selva region and region 4 represents Lima region. For Ecuador, region 1 represents the Sierra region, region 2 represents the Costa region and region 3 represents the Amazon region. For Colombia, region 1 represents the Atlantic region, region 2 represents the Central region, region 3 represents the Eastern region, region 4 represents the Pacific Region, region 5 represents Bogota region and region 6 represents San 
Andres region. For Chile, region 1 represents Norte Grande region, region 2 represents Norte Chico region, region 3 represents Central Nucleus region, region 4 represents Concepción and La Frontera regions, region 5 represents Region of the Lakes, and region 6 represents Region of the Channels. Robust standard errors in parentheses *** $\mathrm{p}<0.01, * * \mathrm{p}<0.05, * \mathrm{p}<0.1$

Table C1. SUR estimates on the time devoted by couples to paid work (even if workers do not receive wages) and unpaid work

\begin{tabular}{|c|c|c|c|c|c|c|c|c|c|c|c|c|}
\hline & (1) & (2) & (3) & (4) & (5) & (6) & (7) & (8) & (9) & (10) & (11) & (12) \\
\hline & \multicolumn{4}{|c|}{ Mexico } & \multicolumn{4}{|c|}{ Peru } & \multicolumn{4}{|c|}{ Ecuador } \\
\hline & Men & Women & Men & Women & Men & Women & Men & Women & Men & Women & Men & Women \\
\hline & \multicolumn{2}{|c|}{ Paid work } & \multicolumn{2}{|c|}{ Unpaid work } & \multicolumn{2}{|c|}{ Paid work } & \multicolumn{2}{|c|}{ Unpaid work } & \multicolumn{2}{|c|}{ Paid work } & \multicolumn{2}{|c|}{ Unpaid work } \\
\hline \multirow[t]{2}{*}{ Sex-ratios } & 0.118 & 0.00577 & $0.139^{* * *}$ & -0.127 & -0.190 & -0.109 & -0.231 & $-0.528^{* * * *}$ & -0.0755 & $-0.358^{* * * *}$ & -0.110 & -0.113 \\
\hline & $(0.118)$ & $(0.111)$ & $(0.0708)$ & $(0.112)$ & $(0.252)$ & $(0.291)$ & $(0.145)$ & $(0.204)$ & $(0.116)$ & $(0.107)$ & $(0.0669)$ & $(0.112)$ \\
\hline \multirow[t]{2}{*}{$\begin{array}{l}\text { Non-la- } \\
\text { bor } \\
\text { income }\end{array}$} & $-0.000578^{*}$ & 0.000136 & 0.000366 & -0.000111 & - & - & - & - & 0.000268 & -0.000249 & $0.00274^{* * *}$ & $0.00163 * *$ \\
\hline & $(0.000321)$ & $(0.000795)$ & $(0.000317)$ & $(0.000478)$ & - & - & - & - & $(0.000632)$ & $(0.000848)$ & $(0.000363)$ & $(0.000690)$ \\
\hline \multirow[t]{2}{*}{$\begin{array}{l}\text { N. chil- } \\
\text { dren } 0-4\end{array}$} & 0.641 & $-3.251 * * *$ & -0.0571 & $2.940 * * *$ & -0.395 & $-6.365^{* * *}$ & -0.414 & $2.259 * * *$ & 0.469 & $-2.080^{*}$ & -0.203 & $2.065^{*}$ \\
\hline & $(0.510)$ & $(0.567)$ & $(0.383)$ & $(0.529)$ & $(0.808)$ & $(1.078)$ & $(0.439)$ & $(0.683)$ & (1.032) & (1.148) & $(0.550)$ & (1.099) \\
\hline \multirow[t]{2}{*}{$\begin{array}{l}\text { N. chil- } \\
\text { dren 5-12 }\end{array}$} & 0.486 & $-2.763^{* * *}$ & -0.0708 & $2.547 * * *$ & 0.595 & $-1.432^{* *}$ & 0.00904 & $1.248^{* * * *}$ & 0.0322 & -0.474 & -0.341 & $1.870 * * *$ \\
\hline & $(0.357)$ & $(0.385)$ & $(0.222)$ & $(0.379)$ & $(0.483)$ & $(0.612)$ & $(0.265)$ & $(0.397)$ & $(0.549)$ & $(0.595)$ & $(0.354)$ & $(0.651)$ \\
\hline \multirow[t]{2}{*}{$\begin{array}{l}\text { N. chil- } \\
\text { dren } \\
13-17\end{array}$} & 0.277 & -0.0198 & 0.0896 & $1.665^{* * * *}$ & -0.310 & -1.241 & 0.421 & 0.490 & 0.290 & -0.661 & 0.383 & 0.594 \\
\hline & $(0.504)$ & $(0.479)$ & $(0.303)$ & $(0.466)$ & $(0.662)$ & $(0.762)$ & $(0.358)$ & $(0.552)$ & $(0.773)$ & $(0.913)$ & $(0.591)$ & $(0.799)$ \\
\hline \multirow[t]{2}{*}{$\begin{array}{l}\text { N. other } \\
\text { house- } \\
\text { hold } \\
\text { members }\end{array}$} & $1.763^{* * * *}$ & 0.375 & $-0.712^{* *}$ & -0.173 & 0.492 & 0.644 & -0.224 & -0.656 & $1.271^{* * *}$ & $0.936^{*}$ & $-0.779 * *$ & -0.435 \\
\hline & $(0.611)$ & $(0.489)$ & $(0.334)$ & $(0.421)$ & $(0.429)$ & $(0.613)$ & $(0.236)$ & $(0.403)$ & $(0.569)$ & $(0.524)$ & $(0.333)$ & $(0.544)$ \\
\hline \multirow[t]{2}{*}{$\begin{array}{l}\text { Years of } \\
\text { education }\end{array}$} & -0.0345 & $0.267 * * *$ & $0.0971^{* *}$ & $-0.515^{* * *}$ & -0.163 & 0.129 & $0.102^{*}$ & $-0.331 * * *$ & -0.166 & 0.151 & 0.00941 & $-0.456^{* * *}$ \\
\hline & $(0.0702)$ & $(0.0685)$ & $(0.0406)$ & $(0.0699)$ & $(0.103)$ & $(0.113)$ & $(0.0541)$ & $(0.0744)$ & $(0.122)$ & $(0.114)$ & $(0.0878)$ & $(0.114)$ \\
\hline \multirow[t]{2}{*}{ Age } & 0.210 & $0.630 * * *$ & -0.0269 & $0.527 * * *$ & -0.0349 & $1.039 * *$ & -0.0802 & -0.224 & $0.717 * * *$ & 0.183 & -0.0484 & 0.332 \\
\hline & $(0.141)$ & $(0.197)$ & $(0.125)$ & $(0.173)$ & $(0.352)$ & $(0.430)$ & $(0.189)$ & $(0.257)$ & $(0.250)$ & $(0.236)$ & $(0.141)$ & $(0.260)$ \\
\hline \multirow[t]{2}{*}{$\begin{array}{l}\text { Age } \\
\text { squared }\end{array}$} & $-0.452 * * *$ & $-0.913 * * *$ & 0.0817 & $-0.496^{* *}$ & -0.0115 & $-1.235^{* *}$ & 0.109 & 0.336 & $-0.982 * * *$ & -0.396 & 0.0759 & -0.306 \\
\hline & $(0.164)$ & $(0.238)$ & $(0.143)$ & $(0.210)$ & $(0.397)$ & $(0.513)$ & $(0.211)$ & $(0.309)$ & $(0.254)$ & $(0.244)$ & $(0.136)$ & $(0.275)$ \\
\hline \multirow[t]{2}{*}{$\begin{array}{l}\text { Indige- } \\
\text { nous }\end{array}$} & - & - & - & - & 1.710 & $5.733 * * *$ & $2.338^{* * * *}$ & -1.271 & -1.154 & 0.0752 & 1.662 & 0.0125 \\
\hline & - & - & - & - & $(1.088)$ & $(1.346)$ & $(0.651)$ & $(0.906)$ & $(2.305)$ & $(2.223)$ & $(1.062)$ & (1.458) \\
\hline \multirow[t]{2}{*}{$\begin{array}{l}\text { Urban } \\
\text { area* }\end{array}$} & $1.945^{* *}$ & $4.666^{* * *}$ & $-2.738 * * *$ & $-9.387 * * *$ & $5.177 *$ & $6.257 * *$ & $-5.936 * * *$ & $-11.82^{* * *}$ & $4.382^{* * * *}$ & 2.014 & $-2.907 * * *$ & $-7.381 * * *$ \\
\hline & $(0.974)$ & (1.028) & $(0.694)$ & $(1.027)$ & $(2.771)$ & $(3.141)$ & $(1.600)$ & (2.183) & $(1.421)$ & (1.363) & $(0.882)$ & (1.337) \\
\hline \multirow[t]{2}{*}{ Region 1} & $2.869 * * *$ & $3.945 * * *$ & -0.705 & $-3.239 * * *$ & $-4.617 * * *$ & -2.040 & 0.469 & $3.214^{* * *}$ & -0.983 & $-9.371 * * *$ & 0.732 & $6.094 * * *$ \\
\hline & $(0.937)$ & $(0.870)$ & $(0.547)$ & $(0.849)$ & (1.333) & $(1.792)$ & $(0.624)$ & $(1.100)$ & $(1.950)$ & $(1.841)$ & (1.053) & (1.852) \\
\hline \multirow[t]{2}{*}{ Region 2} & $-2.205^{* * *}$ & 0.537 & -0.374 & -0.421 & $-6.377 * * *$ & -1.657 & $2.087 * * *$ & $4.398^{* * * *}$ & -1.614 & $-9.095^{* * * *}$ & 0.471 & 1.960 \\
\hline & $(0.729)$ & $(0.837)$ & $(0.525)$ & $(0.795)$ & $(1.390)$ & (1.808) & $(0.668)$ & $(1.111)$ & $(1.601)$ & $(1.591)$ & $(0.792)$ & (1.488) \\
\hline \multirow[t]{2}{*}{ Region 3} & -0.895 & $2.435 * * *$ & $-1.312^{* * *}$ & -1.021 & $-4.811^{*}$ & 0.242 & $2.510^{*}$ & $4.682^{* *}$ & - & - & - & - \\
\hline & $(0.886)$ & $(0.939)$ & $(0.531)$ & $(0.963)$ & (2.534) & $(3.146)$ & (1.335) & (2.109) & - & - & - & - \\
\hline \multirow[t]{2}{*}{ Region 4} & - & - & - & - & - & - & - & - & - & - & - & - \\
\hline & - & - & - & - & - & - & - & - & - & - & - & - \\
\hline \multirow[t]{2}{*}{ Region 5} & - & - & - & - & - & - & - & - & - & - & - & - \\
\hline & - & - & - & - & - & - & - & - & - & - & - & - \\
\hline
\end{tabular}


Table G1. (continued). SUR estimates on the time devoted by couples to paid work (even if workers do not receive wages) and unpaid work

\begin{tabular}{|c|c|c|c|c|c|c|c|c|c|c|c|c|}
\hline & (1) & (2) & (3) & (4) & (5) & (6) & (7) & (8) & (9) & (10) & (11) & (12) \\
\hline & \multicolumn{4}{|c|}{ Mexico } & \multicolumn{4}{|c|}{ Peru } & \multicolumn{4}{|c|}{ Ecuador } \\
\hline & Men & Women & Men & Women & Men & Women & Men & Women & Men & Women & Men & Women \\
\hline & \multicolumn{2}{|c|}{ Paid work } & \multicolumn{2}{|c|}{ Unpaid work } & \multicolumn{2}{|c|}{ Paid work } & \multicolumn{2}{|c|}{ Unpaid work } & \multicolumn{2}{|c|}{ Paid work } & \multicolumn{2}{|c|}{ Unpaid work } \\
\hline \multirow[t]{2}{*}{ Year 1} & -1.278 & $2.935^{* * * *}$ & -0.924 & $3.308^{* * * *}$ & - & - & - & - & - & - & - & - \\
\hline & $(1.083)$ & $(1.075)$ & $(0.742)$ & (1.094) & - & - & - & - & - & - & - & - \\
\hline \multirow[t]{2}{*}{ Year 2} & $-3.553^{* * * *}$ & $1.756^{* * * *}$ & $-1.641 * * * *$ & $-3.307 * * *$ & - & - & - & - & - & - & - & - \\
\hline & $(0.517)$ & $(0.563)$ & $(0.293)$ & $(0.490)$ & - & - & - & - & - & - & - & - \\
\hline \multirow[t]{2}{*}{ Constant } & $44.39 * * *$ & $23.39^{* *}$ & 0.407 & $49.65^{* * * *}$ & $77.66^{* * * *}$ & 22.95 & $37.47 * *$ & $97.86^{* * *}$ & $46.85^{* * *}$ & $83.93^{* * *}$ & $21.48^{* * * *}$ & $41.12^{* * * *}$ \\
\hline & $(12.07)$ & (11.83) & (8.098) & (11.62) & $(28.08)$ & $(32.15)$ & $(16.22)$ & $(22.33)$ & $(15.20)$ & $(13.45)$ & $(8.117)$ & (13.73) \\
\hline $\begin{array}{l}\text { Observa- } \\
\text { tions }\end{array}$ & \multicolumn{2}{|c|}{8500} & \multicolumn{2}{|c|}{8500} & \multicolumn{2}{|c|}{1334} & \multicolumn{2}{|c|}{1334} & \multicolumn{2}{|c|}{1742} & \multicolumn{2}{|c|}{1742} \\
\hline
\end{tabular}

Notes: Data sources are time-use surveys from Mexico (2002,2009,2014), Peru (2010), Ecuador (2012), Colombia $(2012,2017)$ and Chile (2015). The sample is restricted to heterosexual couples who are not students or retired. *Weekly hours for paid and unpaid work are considered for Mexico, Peru, Ecuador, and Chile and daily hours for paid and unpaid work are considered for Colombia. For Mexico, region 1 represents the Centre region, region 2 represents the West-centre region, region 3 represents the North region and region 4 represents the Southsoutheast region. For Peru, region 1 represents the Rest of the Coast region, region 2 represents the Sierra region, region 3 represents the Selva region and region 4 represents Lima region. For Ecuador, region 1 represents the Sierra region, region 2 represents the Costa region and region 3 represents the Amazon region. For Colombia, region 1 represents the Atlantic region, region 2 represents the Central region, region 3 represents the Eastern region, region 4 represents the Pacific Region, region 5 represents Bogota region and region 6 represents San Andres region. For Chile, region 1 represents Norte Grande region, region 2 represents Norte Chico region, region 3 represents Central Nucleus region, region 4 represents Concepción and La Frontera regions, region 5 represents Region of the Lakes, and region 6 represents Region of the Channels. Robust standard errors in parentheses $* * *$ $\mathrm{p}<0.01, * * \mathrm{p}<0.05, * \mathrm{p}<0.1$

Table C2. SUR estimates on the time devoted by couples to paid work (even if workers do not receive wages) and unpaid work

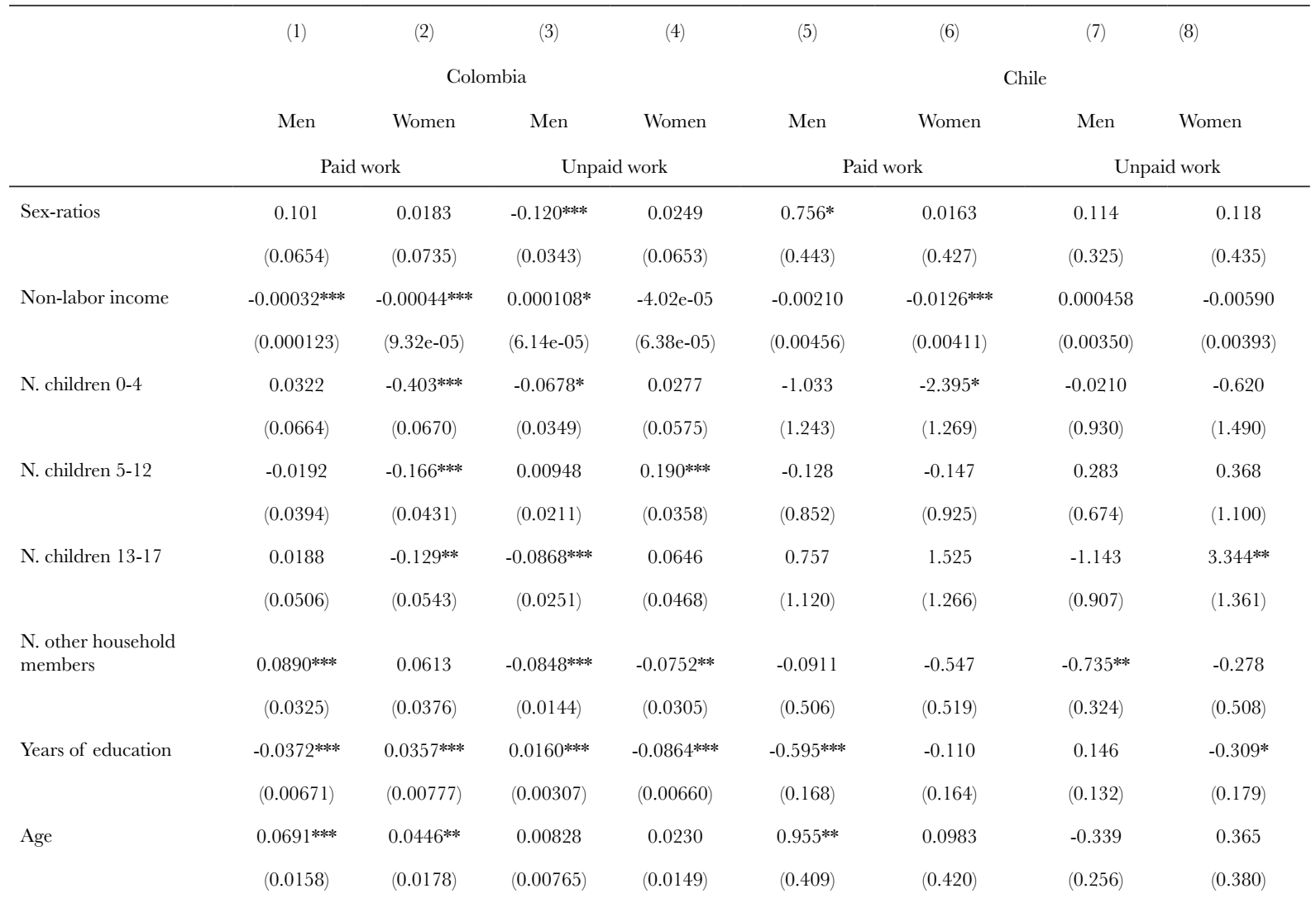


Table C2. (continued). SUR estimates on the time devoted by couples to paid work (even if workers do not receive wages) and unpaid work

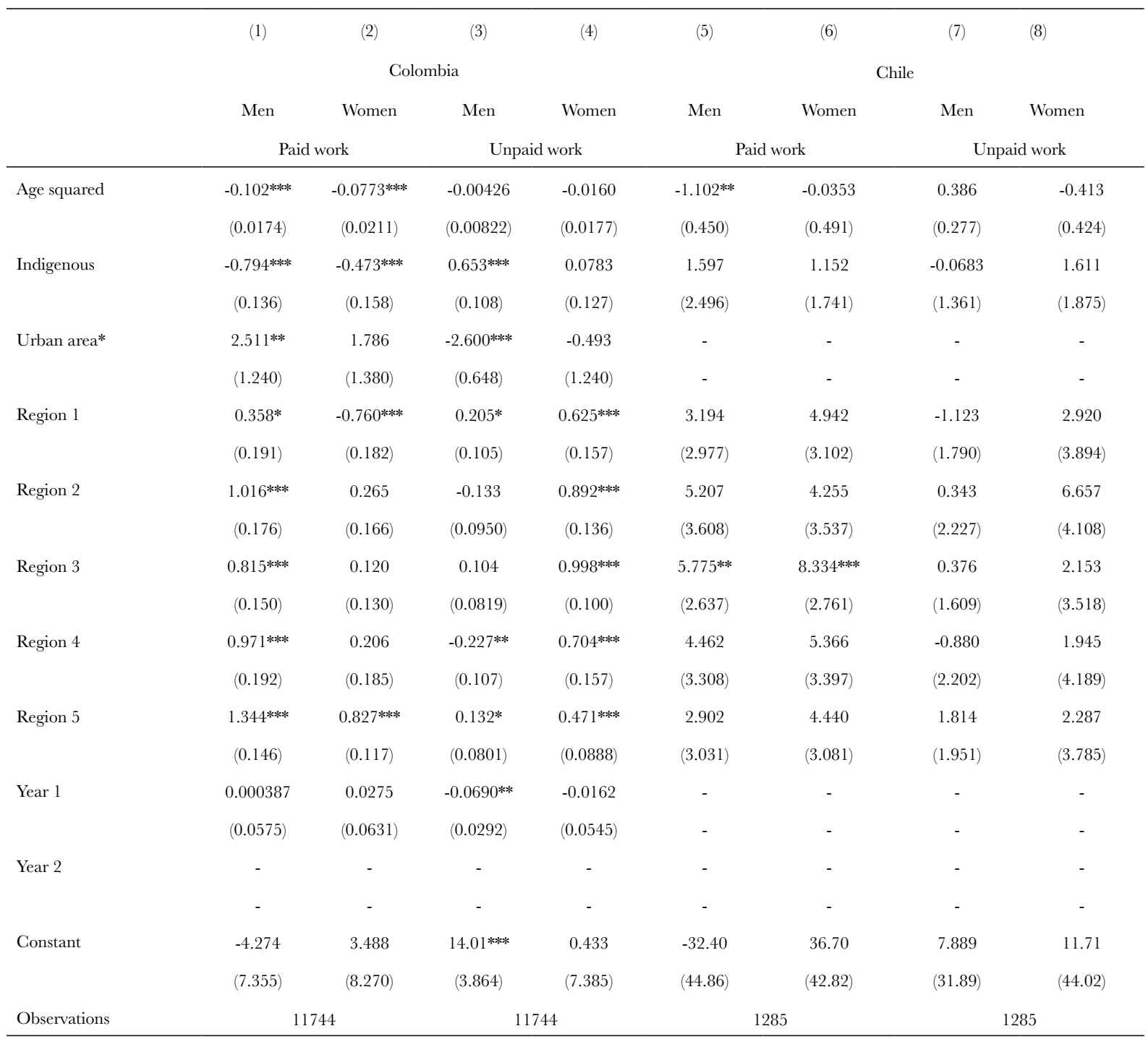

Notes: Data sources are time-use surveys from Mexico (2002,2009,2014), Peru (2010), Ecuador (2012), Colombia $(2012,2017)$ and Chile (2015). The sample is restricted to heterosexual couples who are not students or retired. *Weekly hours for paid and unpaid work are considered for Mexico, Peru, Ecuador, and Chile and daily hours for paid and unpaid work are considered for Colombia. For Mexico, region 1 represents the Centre region, region 2 represents the West-centre region, region 3 represents the North region and region 4 represents the Southsoutheast region. For Peru, region 1 represents the Rest of the Coast region, region 2 represents the Sierra region, region 3 represents the Selva region and region 4 represents Lima region. For Ecuador, region 1 represents the Sierra region, region 2 represents the Costa region and region 3 represents the Amazon region. For Colombia, region 1 represents the Atlantic region, region 2 represents the Central region, region 3 represents the Eastern region, region 4 represents the Pacific Region, region 5 represents Bogota region and region 6 represents San Andres region. For Chile, region 1 represents Norte Grande region, region 2 represents Norte Chico region, region 3 represents Central Nucleus region, region 4 represents Concepción and La Frontera regions, region 5 represents Region of the Lakes, and region 6 represents Region of the Channels. Robust standard errors in parentheses $* * *$ $\mathrm{p}<0.01, * * \mathrm{p}<0.05, * \mathrm{p}<0.1$

Table D1. Descriptive statistics of the time devoted to paid work, considering hourly wages (quartiles)

\begin{tabular}{|c|c|c|c|c|c|c|}
\hline \multirow[b]{2}{*}{ Quartile } & \multicolumn{2}{|c|}{ Mexico } & & & \multicolumn{2}{|c|}{ Ecuador } \\
\hline & Men & Women & Men & Women & Men & Women \\
\hline
\end{tabular}




\begin{tabular}{lccccccccccccc} 
& Mean & S.D & Mean & S.D & Mean & S.D & Mean & S.D & Mean & S.D & Mean & S.D \\
\hline Quartile 1 & 63.59 & 19.36 & 46.61 & 22.71 & 58.67 & 15.14 & 40.59 & 19.59 & 54.43 & 15.85 & 42.92 & 18.40 \\
Quartile 2 & 59.80 & 16.10 & 45.95 & 18.47 & 59.61 & 13.20 & 40.36 & 19.01 & 56.31 & 14.87 & 43.60 & 17.25 \\
Quartile 3 & 56.20 & 15.16 & 39.51 & 17.87 & 58.61 & 14.11 & 36.72 & 17.63 & 49.65 & 13.52 & 43.81 & 14.02 \\
Quartile 4 & 49.71 & 16.90 & 35.54 & 17.62 & 51.67 & 15.10 & 28.19 & 16.83 & 47.79 & 12.78 & 41.00 & 11.23 \\
Observations & & \multicolumn{2}{c}{6202} & & & & & & & & & & \\
\hline
\end{tabular}

\begin{tabular}{lccccccccc}
\hline \multirow{2}{*}{ Quartile } & \multicolumn{4}{c}{ Colombia } & \multicolumn{3}{c}{ Chile } \\
& Men & \multicolumn{3}{c}{ Women } & \multicolumn{2}{c}{ Men } & \multicolumn{2}{c}{ Women } \\
& Mean & S.D & Mean & S.D & Mean & S.D & Mean & S.D \\
\hline Quartile 1 & 9.75 & 2.66 & 7.44 & 3.05 & 59.29 & 19.25 & 46.91 & 21.89 \\
Quartile 2 & 9.77 & 2.25 & 8.44 & 2.85 & 57.94 & 17.34 & 50.11 & 16.80 \\
Quartile 3 & 9.58 & 2.27 & 8.36 & 2.24 & 56.20 & 16.54 & 46.51 & 17.16 \\
Quartile 4 & 9.03 & 2.3 & 8.04 & 2.53 & 51.58 & 15.41 & 43.66 & 12.97 \\
Observations & \multicolumn{3}{c}{9842} & & & & & & \\
\hline
\end{tabular}

Notes: Quartile 1 represents lowest income per hour, Quartile 2 represents low income per hour), Quartile 3 represents high income per hour and Quartile 4 represents highest income per hour. Data sources are time-use surveys from Mexico (2002, 2009, 2014), Peru (2010), Ecuador (2012), Colombia (2012, 2017) and Chile (2015). The sample is restricted to heterosexual couples who are not students or retired. *Weekly hours of work are considered for México, Peru, Ecuador and Chile and daily hours of work for Colombia **For Mexico 1 US dollar, equivalent to 10.17 Mexican pesos (exchange rate 2002), For Peru 1 US dollar, equivalent to 2.811 Peruvian soles. For Colombia 1 US dollar, equivalent to 1817.52 Colombian pesos (exchange rate 2012). And for Chile it is 1 US dollar, equivalent to 697.33 Chilean pesos. For Mexico, in the case of men, Quartile 1 is between 0.001 and 1.04 dollars, Quartile 2 is between 1.05 and 1.62 dollars, Quartile 3 is between 1.63 and 2.65 dollars and Quartile 4 is between 2.66 and 12.43 dollars. And in the case of women, Quartile 1 is between 0.001 and 0.84 dollars, Quartile 2 is between 0.85 and 1.41 dollars, Quartile 3 is between 1.42 and 2.61 dollars and Quartile 4 is between 2.62 and 10.81 Dollars. For Peru, in the case of men, Quartile 1 is between 0.05 and 0.95 dollars, Quartile 2 is between 0.96 and 1.39 dollars, Quartile 3 is between 1.40 and 2.13 dollars and Quartile 4 is between 2.14 and 24.90 dollars. And in the case of women, Quartile 1 is between 0.04 and 0.75 dollars, Quartile 2 is between 0.76 and 1.21 dollars, Quartile 3 is between 1.22 and 2.08 dollars and Quartile 4 is between 2.09 and 32.61 dollars. For Ecuador, in the case of men, Quartile 1 is between 0.03 and 1.08 dollars, Quartile 2 is between 1.09 and 1.61 dollars, Quartile 3 is between 1.62 and 2.36 dollars and Quartile 4 is between 2.37 and 13.26 dollars. And in the case of women, Quartile 1 is between 0.03 and 0.85 dollars, Quartile 2 is between 0.86 and 1.43 dollars, Quartile 3 is between 1.44 and 2.13 dollars and Quartile 4 is between 2.14 and 15.96 Dollars. For Colombia, in the case of men, Quartile 1 is between 0.001 and 1.13 dollars, Quartile 2 is between 1.14 and 1.64 dollars, Quartile 3 is between 1.65 and 2.57 dollars and Quartile 4 is between 2.58 and 42.79 dollars. And in the case of women, Quartile 1 is between 0.001 and 0.88 dollars, Quartile 2 is between 0.89 and 1.52 dollars, Quartile 3 is between 1.53 and 2.15 dollars and Quartile 4 is between 2.16 and 24.87 Dollars. For Ghile, in the case of men, Quartile 1 is between 0.14 and 2.17 dollars, Quartile 2 is between 2.18 and 3.20 dollars, Quartile 3 is between 3.21 and 5.55 dollars and Quartile 4 is between 5.56 and 23.90 dollars. And in the case of women, Quartile 1 is between 0.02 and 1.67 dollars, Quartile 2 is between 1.68 and 2.38 dollars, Quartile 3 is between 2.39 and 4.18 dollars and Quartile 4 is between 4.19 and 16.36 Dollars. 